\title{
Market Definition Analysis in Latin America with Applications to Internet-Based Industries
}

\author{
DAVID S. EVANS* \& ELISA V. MARISCAL ${ }^{* *}$
}

\begin{abstract}
There has been a surge of recent antitrust cases involving Internet-based industries around the world, including in Latin America. These types of industries present special challenges for authorities, as their analysis requires an understanding of the fast-paced, innovative, and multisided nature of these businesses. In this paper we present methods and techniques for market definition and power analysis which emphasize the need to focus on competitive constraints rather than structural or functional characteristics of products and services-a particularly relevant issue in Internet-based industries. We next explore whether the legal frameworks of Argentina, Brazil, and Mexico can accommodate this type of analyses. Our focus then shifts to how competition takes place in Internet-based industries; we describe how firms vie for consumer attention and provide this attention to advertisers and developers using the concept of "attention rivalry." Taking this theoretical background into account, we pose the question of whether the three largest Latin American economies have the tools, legal ability, and expertise to undertake these types of complex analyses. We use cases to illustrate where they
\end{abstract}

\footnotetext{
* Evans is Founder, Market Platform Dynamics; Lecturer, University of Chicago Law School; Executive Director, Jevons Institute for Competition Law and Economics and Visiting Professor, University College London (devans@marketplatforms.com).

** Mariscal is Managing Director, Market Platform Dynamics; Visiting Professor, Centro de Investigación y Docencia Económicas (CIDE) and Lecturer Instituto Tecnológico Autónomo de México (ITAM) (emarsical@marketplatforms.com). We would like to thank Alexis Pirchio for excellent research help and Google for research support. We retain sole ownership of any errors.
} 
have done so, and review the most relevant work they have undertaken in Internet-based industries since 2000. In our view, nothing prevents competition agencies in these countries from conducting the correct economic analyses.

\section{INTRODUCTION}

Antitrust has expanded rapidly in Latin America over the last two decades as a result of economic development in a number of countries, and the effort to open up to competition former public monopolies, such as telecom and electricity, and to modernize regulatory institutions charged with overseeing them. These efforts have been part of a push to change the drivers of economic growth from those that emphasized the government's role in leading the economy to one that considers market-based competition to be best in spurring economic performance. By the end of 2012, seventeen of the twenty Latin American countries had competition laws and authorities in place to enforce them. The first country that adopted a modern competition law was Chile in 1973, but since then the remaining authorities have adopted new laws, with the Dominican Republic being the most recent one in 2008. Tellingly, the current head of the International Competition Network is the President of the Mexican Federal Competition Commission.

As with many countries, the practice of competition law enforcement is a work in progress in Latin American countries. Competition authorities and courts are developing best practices often by adapting methods that have been refined in other jurisdictions to their national contexts. The purpose of this paper is to gauge whether there is room in the current legislations for following some of these best practices for defining markets, and analyzing market power, in merger and monopolization cases, and to highlight their importance when studying Internet-based industries. Market definition and market power are usually the foundations on which merger and monopolization analyses are based. Getting this part of the analysis correct is therefore essential.

Some of the most complex applications of antitrust analysis concern Internet-based industries. These industries pose challenges to the traditional analysis of market definition and market power in part because they are highly dynamic and the boundaries between products are typically fluid. ' In Latin America, as in most other parts

${ }^{1}$ Douglas H. Ginsburg and Joshua D. Wright, Dynamic Analysis and the Limits of Antitrust Institutions, 78 ANTITRUST L. J. 1 (2012), available at http://ssrn.com/abstract $=\mathbf{2 0 8 4 3 5 5}$. 
of the world, Internet-based industries have become increasingly important in the economies. Around twenty years after the birth of commercial Internet the pace of change is accelerating as a result of greater access to the Internet. A key contributor to this acceleration has been the deployment of smart mobile devices and applications that run on these devices, which are connected to the Internet. ${ }^{2}$ For this reason, to illustrate best practices in a complex, fast changing and innovative environment, this paper focuses on the analysis of market definition and power in Internet-based industries for the three Latin American economies that have already begun to review and investigate these industries: Argentina, Brazil, and Mexico.

The paper is organized as follows. Section I describes methods and techniques for market definition and market power analysis. The section is meant to provide background on the type of analyses based on international best practices that are currently being undertaken by different authorities. It is based in part on guidelines the authors developed for Mexico. ${ }^{3}$

The next section looks at the legal frameworks underlying relevant market and market power determination in the three largest Latin American countries. We also look at how relevant market guidelines for each of these countries support or expand on the elements included in the laws. There is a tendency particularly in less mature agencies-not required by the law and unfounded in economic principles-to use mechanical approaches to market definition and market power. In this, Latin America is not unique, as actual and best practices will sometimes deviate.

Section III then turns to market definition in Internet-based industries. It focuses on market definition for a class of Internet-based firms that we call "attention rivals". These firms vie for the time of consumers and then direct some of that attention to advertisers. The competitive constraints for attention rivals comes from other attention rivals regardless of whether they are offering the same product or service. That, in part, is the explanation for the fact that it

\footnotetext{
${ }^{2}$ Growing arrays of other devices are also being connected to the Internet, such as television sets, point-of-sale devices for card acceptance, and household appliances.

3 Federal Competition Commission of Mexico, Assessment of Market Power in Competition Matters, (March 2011), available at

http://www.cfc.gob.mx/images/stories/Documentos/guias/ultdoctopodersustmercado.pdf [hereinafter, Market Power Report]; Federal Competition Commission of Mexico, Assessment of the Relevant Market in Competition Matters, (March 2011), available at http://www.cfc.gob.mx/images/stories/Documentos/guias/doctoreferenciadefmercreleva nt.pdf [hereinafter, Market Definition Report].
} 
is widely perceived that Amazon, Apple, Facebook, and Google are each other's most significant rivals even though each specializes in very different products and services. The section concludes with a discussion of the European Commission's decision approving Microsoft's acquisition of Skype-an example that used most of the principles we outline throughout this paper.

Section IV poses the question as to whether Latin America's antitrust authorities in its three largest economies have the technical know-how, experience, and the operate under a sufficiently flexible legal framework-which we review in detail in section II-to apply best practices and undertake complex analyses in internet-based industries. In this section we begin by addressing the issue of experience in undertaking complex analyses by presenting examples of casework, unrelated to Internet-based industries, for each country where authorities have used some of the principles we outlined in section II. We then summarize the types of Internet-based cases that have historically come up in these jurisdictions since 2000. Although the degree of complexity of these cases has not yet required the tools and analyses we discuss here, in our opinion, there is a good possibility that authorities will be in a position to apply these tools to future Internet-related cases.

\section{Best Practices for MARKet Definition AND MARKET POWER}

The purpose of market definition is to identify the competitive constraints on the supplier of the product under consideration - the market forces that reduce the profitability of raising prices above competitive levels or lowering quality. If the buyers of a particular product from firm A can realistically only turn to firm B if firm A raises its prices substantially, for instance, then B provides the only competitive constraint on A. In general, the strength of the competitive constraints determines whether practices engaged in by the supplier of the product under consideration, or the combination of two or more suppliers, could harm competition and consumers. For example, it is unlikely that the merger of two firms could harm competition if consumers could turn to many alternative and comparable suppliers. Those firms, once merged, would not be able to raise prices because consumers would simply buy elsewhere.

Market definition is closely related to the assessment of market power. 4 Market power concerns the ability of a supplier of a product to

4 For further discussion, see Market Power Report. 
charge prices that are significantly higher than those that would occur under perfect (i.e., very intense) competition. Most businesses have some market power; business practices are anticompetitive only when engaged in by those with substantial market power (with the exception of hardcore cartel behavior, of course). A particular business practice, such as entering into exclusive contracts, could harm competition if the supplier has substantial market power but could be benign if the supplier does not have such power. Likewise, a merger of two firms could only result in higher prices if the concentration results in the merged firm having significantly greater market power than either firm had alone. Market definition is the first step in assessing market power; it identifies the sources of competitive constraints that determine the degree of power that a supplier (or a combination of suppliers) likely has. The weaker the competitive constraints a firm faces, the greater its market power.

Market definition is not, however, an end in itself. This analytical device is useful only to the extent that it assists in assessing the competitive constraints that are relevant for the matter under consideration. In fact, the assessment of the relevant market could lead to significant error if it resulted in ignoring competitive constraints, as this could lead to the false conclusion that practices are harmful to competition, or if it resulted in exaggerating competitive constraints, as this could lead to the false conclusion that the practices are lawful.

Several practices are advisable to minimize errors in market definition. We list these as recommendations next.

\section{A. Identifying Competitive Constraints}

\section{Always Come Back to Competitive Constraints}

Since the ultimate purpose of the analysis of market definition and power is to assess competitive constraints it is important that the analysis of the relevant market and market power accurately reflect these constraints. Therefore, best practice requires that each of these competitive constraints-or lack thereof-are carefully considered in the analysis.

There are several key competitive constraints that could limit the ability of the supplier of the product at issue to make changes that are adverse to the interest of consumers. Assessing whether a merger or competitive conduct harms consumers often requires the balancing of positive and negative effects, including price, quality, and the rate of innovation. It is important to focus on "net" changes since is it possible that price could increase but that consumers would be better off because the quality of the product more than compensates for the 
increase in price; or that price could fall but not enough to compensate for reductions in quality or other factors. In such an assessment, key competitive factors include:

- Demand substitutability. Could consumers turn to other products so that an adverse change by the producer would result in consumers reducing consumption of its product in favor of other products?

- Switching costs. Can consumers readily switch to an alternative product or do they incur costs that would make them captive to the supplier at issue?

- Multihoming. Do consumers have ready access to several alternative versions of a product or service so that they could easily switch from one version if it imposed adverse conditions? The concept of multihoming is particularly relevant when consumers make sequential decisions to "join" a service (e.g., a particular type of payment card) and "use" the service (e.g., using a type of card available to pay a merchant).

- Supply substitutability. Could other producers of substitute products expand output to avail themselves of increased demand by consumers for alternatives to the product at issue?

- Entry. Could new firms enter in competition with the supplier of the product at issue or could existing firms switch production capacity to supply substitute products?

- Innovation. Does incremental or drastic innovation occur rapidly enough to either make significant market power temporary or to force the supplier at issue to both improve its product and limit any adverse changes? 
- Buyer power. Do buyers of the product at issue have significant market power that could prevent or limit the supplier of the product at issue from making adverse changes?

- Complementary products. Does the supplier at issue supply complementary products whose demand, and profitability, would fall if it made adverse changes? A special case of this involves multi-sided platforms that serve as intermediaries between multiple customer groups. An adverse change to consumers on one side would reduce the value received and the price paid on the other side.

- Regulation. Do regulatory constraints limit the ability of the supplier at issue to make adverse changes? Alternatively do regulatory constraints limit the ability of new firms to enter the market or expand output?

Unfortunately, through statutes, case law, or actual practice by enforcement agencies, some jurisdictions have adopted approaches that limit the ability to consider some of these constraints in defining the relevant market. Moving toward best practice requires the consideration of these constraints as part of the assessment of market power and whether the conduct at issue harms consumers. Errors arise when the analysis ignores one or more of these constraints in the market definition exercise and then refuses to consider them, or treats them in passing, in the remainder of the analysis. Failure to properly weigh these competitive constraints not only causes mistakes in market definition; it encourages parties to a dispute to believe that whoever wins the market definition battle will win the war and thereby puts undue emphasis on market definition.

\section{Focus on "Marginal" Consumers}

The basic question that motivates the assessment of market power is whether enough consumers would switch to substitute products in response to a price increase by a supplier of the product under consideration to make the price increase unprofitable. The consumers who are most likely to switch are "marginal consumers" who were already predisposed to consider other products because they view 
them as good substitutes. If there are enough of these consumers who would switch then the price increase would not be profitable. Identifying, measuring, and estimating the behavior of these marginal consumers is critical to best practice market definition.

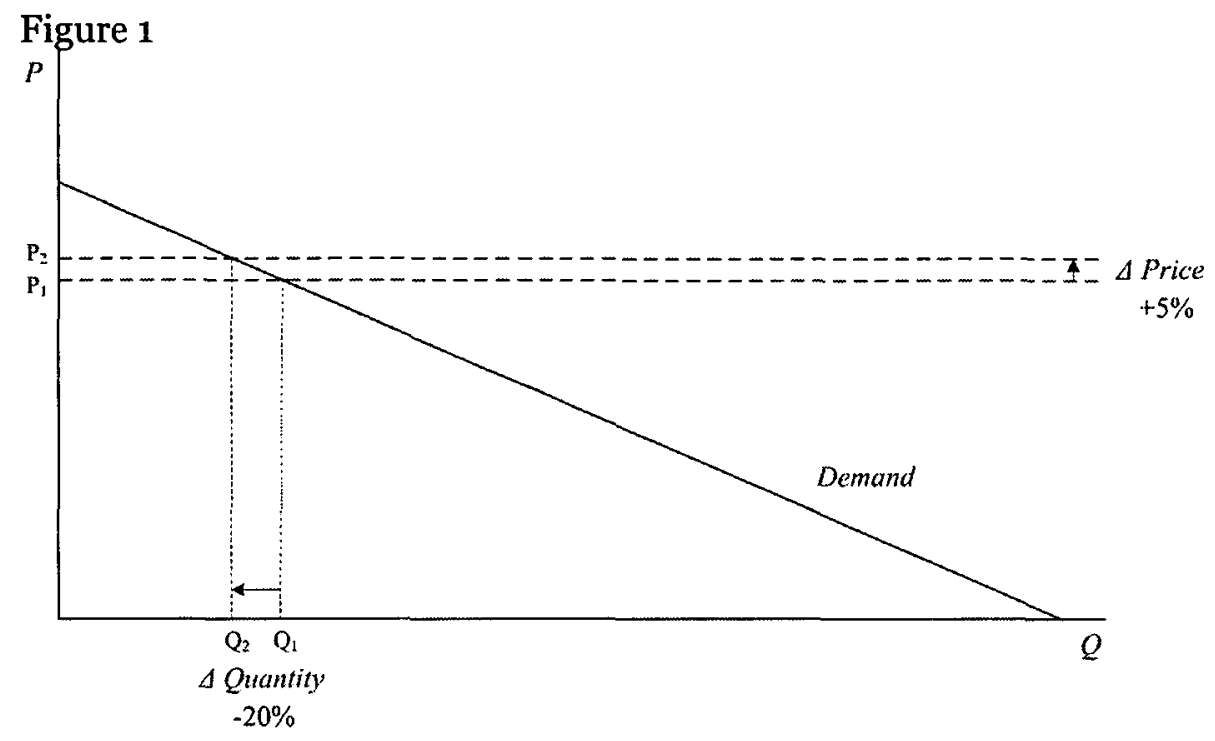

Figure 1 above illustrates this point by considering the case where every consumer buys at most one unit, a reasonable approximation for some durable-goods markets (e.g., central air conditioners or washing machines). Consumers are, in effect, listed on the demand schedule at the point corresponding to the most they would be willing to pay for the good. The diagram shows the case where a 5 percent price increase results in a 20 percent decrease in the quantity demand, as a result of there being a significant number of consumers at the margin between wanting to buy the product in question rather than substitute products. Once the price goes up, they switch.

A common mistake in the analysis of market definition and market power is to focus on what the "typical" or "average" consumer would do. The typical or average consumer may not in fact switch to substitute products when a supplier increases its price. That is the case shown in Figure 1. But it usually is not the average consumer who determines whether a supplier can profit from a price increase. So long as there are enough consumers "at the margin" between the supplier's product and alternatives, the price increase cannot result in greater profits. Suppose, for example, that a firm has variable cost per unit of $\$ 5$ and would sell 100 units at a price of $\$ 10$ for a profit, before 
fixed costs, of $\$ 500$. (This may or may not be enough to cover fixed costs, of course.) Suppose 80 percent of consumers would buy from this supplier even with a small price increase of say $\$ 1$, so that the "typical" consumer will not switch in response to this price change. But suppose that 20 percent are extremely price sensitive, so that if this firm raised its price to $\$ 11$, all would switch to another product. That would reduce sales to 80 units and reduce profit before fixed costs to $\$ 480$, making the price increase unprofitable. For details of how to analyze this in practice, see Section III below. 5

When there is product differentiation, which is present in most real-world markets, there may be discrete categories of consumers that will switch from a product in question at various price points or based on particular product attributes. Depending on what the price is, and how much it is changing, many or a few consumers might switch in response to a price change. Understanding how the market is segmented is important in these cases. For example, telecommunications cases have often brought up the question of whether fixed and mobile phones are substitutes and whether price changes would entice consumers to switch from one to the other. Although, for some consumers, phones-whether fixed-line or mobile-may represent a means of voice communication, in reality the ability to communicate by voice "on the move" using the latter means that for mobile phone consumers, a fixed-line phone is probably not a good substitute even ignoring the other features that mobile phones provide; the same of course is not true for fixed-line phones for which a mobile phone may well be a good substitute. In both cases, it is the number of consumers who would likely switch (the marginal consumers) that will determine whether these products are, or are not, good substitutes.

\section{Use the Right Basis for Assessing Competitive Constraints}

One of the consequences of a firm already having significant market power is that the firm may have raised the price so much that marginal consumers might have already switched to poor substitutes. This is the well-known cellophane paradox based on a US case. ${ }^{6}$ The cellophane producer had raised prices so high that the marginal consumers considered paper and other methods for covering food as

5 See also, Market Definition Report, Section 2.

${ }^{6}$ George W. Stocking and Willard F. Mueller, The Cellophane Case and the New Competition, THE AMERICAN ECONOMIC REVIEW Vol. 45, No. 1 (1955): 29-63, available at http://www.jstor.org/stable/1811582. 
alternatives. The only reason these products were substitutes is because the firm had exercised market power. The cellophane paradox highlights the fact that the analysis of market definition and market power needs to be careful about the vantage point from which it is assessing market power.

In a monopolization matter, the relevant question ordinarily concerns whether the party at issue in the case has significant market power. For this purpose the question is whether it is currently able to adopt pricing and related policies that differ significantly from what a competitive firm would do. Thus, the benchmark for assessing competitive constraints is the constraints that would limit a competitive producer of the product. In particular, the relevant demand-side substitutes are the ones that consumers would consider if price were increased from the competitive level.

In a merger matter, by contrast, the relevant question concerns whether the merging parties could, through their combination, make things worse for consumers. In this case the relevant question is whether, given the state of the industry today, competitive constraints would limit the merging parties from raising prices. The fact that either or both merging parties have significant market power does not affect the analysis since for the purposes of a merger review competition law usually accepts the market as it is now. It is only the worsening of market conditions that causes antitrust concerns. So here, the relevant demand-side substitutes are the ones that consumers would consider if prices were increased from the current level even if the current level is not competitive.

\section{Recognize that No Real Competitive Market Looks Like Textbook Competition}

There are two features of real-world competitive markets that competition analysis needs to account for.

First, almost all real-world markets involve products and services that are differentiated from each other. Consumers have different preferences for products and services and different needs depending on their circumstances. People even of the same income like different kinds of beer and different types of cars. There is therefore a market opportunity to cater to these preferences and needs. Businesses respond to these market opportunities by creating different types of products and coming up with innovations that will appeal to particular people. Businesses have strong incentives to exploit the differences. There are usually limited profit opportunities in producing the same product and service as everyone else. Therefore, hardly anything is a perfect substitute for anything else. But many 
products are imperfect substitutes and these, individually or collectively, could constrain the ability of a firm to impose adverse conditions on consumers.

Second, most seemingly competitive real-world industries do not, and cannot, operate at the point where price equals marginal cost-the equilibrium that maximizes welfare in the standard model of perfect competition used by economists.7 The reason is that most firms incur fixed costs including the fixed costs of establishing the business in the first place. To recover these fixed costs, and therefore earn at least a competitive return on their capital, they have to charge prices that are in excess of marginal cost; that is they must have a positive operating margin to cover their costs. Many firms in seemingly competitive industries engage in value pricing-that is price discrimination-to earn enough profit from various subsets of consumers to cover their fixed costs of production.

\section{Collect Evidence from Multiple Sources}

In practice, competition policy analysis seldom has available conclusive evidence. Most types of evidence are subject to frailties or open to interpretation. By combining multiple sources of evidence, however, it is possible to reach more robust conclusions. Key sources of evidence include:

- Interchangeability information. Do consumers switch between products based on common knowledge? That is, are there documents, studies or other evidence that would provide information on the relative ease or difficulty of adopting different technologies or switching to alternative products? Is this a simple process or does it require specialized knowledge or learning? Do all consumers or only some consumers do this? This may help focus the analysis on the marginal consumer.

- Company records on competitors. Who do company executives say they compete with? Sales force documents, minutes of meetings among senior management, securities filings,

7 Louis Kaplow and Carl Shapiro, Antitrust, HARVARD LAW AND ECONOMICS DISCUSSION

PAPER NO. 575 (2007), available at http://ssrn.com/abstract $=961264$. 
and public documents such as those provided to investors may say. Especially when produced in the normal course of business such evidence is highly informative.

- Win-loss sales reports. What do company sales records show about who they win sales from and who they lose sales from most frequently (particularly important for business to business, or $\mathrm{B} 2 \mathrm{~B}$ ). This is particularly strong evidence on who effectively constrains a company in the marketplace.

- Customer surveys. These are surveys whose questionnaires have been designed to obtain an insight into consumer reactions to price increase. They ask consumers what products they would switch to if prices went up. They also allow to better focus on marginal vs. average consumers.

- Statistical estimates. Conduct statistical analysis of historical data on prices and demand. Historical analysis can prove useful in determining whether recent price information is indeed the right basis for assessing competitive constraints, nevertheless, even what economists note as "data regularities" may not necessarily be regular and additional evidence is also beneficial.

- Natural experiments. Compare demand patterns between different places with different prices. These types of analyses are very useful provided that allowances are made for variables that can capture and isolate differences not solely explained by price variations.

- Standard tests used to analyze mergers and antitrust cases, with a particular focus on price. Hypothetical monopolist test or small but significant and non-transitory increase in price 
(SSNIP) test. We would caution on the use of these tests, however, as they tend to focus on price competition only, and ignore other dimensions of competition that are relevant to a firm's business.

We now look at the underlying legal institutions as well as the case law, which governs competition determinations in the three largest Latin American economies. We seek to determine whether these best practices are either explicitly mentioned or whether there are legal impediments to their application.

\section{Case Law and Decisional Practice in Latin America}

It is widely recognized among antitrust authorities and practitioners that competition analysis needs to incorporate economic thinking in decisions. Furthermore, there needs to be a flexible approach in employing economic tools to diverse industries, and to accommodate technological change. The recent Organisation for Economic Co-operation and Development (OECD) Roundtable discussions on Market Definition, ${ }^{8}$ for example, note the importance of recognizing the existence of multiple methods to arrive at an answer for the main goal of market definition: to capture competitive constraints faced by a firm as accurately as possible.

Over the last 25 years, many jurisdictions around the world have made an effort to modernize their approach to antitrust. It began in the US in the mid-1970s, when courts began incorporating economic analysis into their decisions, and was continued and deepened as authorities issued the 1982 merger guidelines. In Latin America, this effort to make transparent its use of economic tools in antitrust analysis is just underway, with the publication of guidelines starting in the late 1990 s. It is not a simple undertaking.

Modernizing antitrust can be a more challenging exercise in countries with civil law traditions that tend to have hierarchical laws each with a precise interpretation mostly based on the letter of the law and not always its intent. Changes to the interpretation of this vast body of laws very often require a redrafting of the statutes by the legislative branch. It is particularly challenging in countries whose

\footnotetext{
8 OECD Policy Roundtables, Market Definition, DIRECTORATE FOR FINANCIAL AND ENTERPRISE AFFAIRS, Competition Committee (2012), available at http://www.oecd.org/daf/competition/Marketdefinition2012.pdf.
} 
legal systems have tended to be particularly formal, or whose judges are not entirely attuned to a subject so intricately related with economics. Nevertheless, Latin America can look to other jurisdictions for some direction. In the US and the EU there has been a push for more economic thinking, particularly in merger cases. ${ }^{9}$ Both these jurisdictions have followed up by modernizing their approaches to market definition through guidelines, and/or notices and regulations that have inserted economic thinking into decisions.

With rapid technological advances revolutionizing many industries, it is critically important to modernize antitrust analysis. Internet, mobile, and other technological changes have made traditional formalistic methods obsolete, as these were designed for industrial settings that were fundamentally different from the dynamic and fluid industries that authorities are increasingly addressing in mergers or conduct cases. There is a clear recognition of this among most mature competition agencies around the world, as emphasized in the OECD discussion paper cited above.

By reviewing the legal frameworks of Argentina, Brazil, and Mexico in this section, we make a case that there is nothing holding back Latin American countries from following the modernization efforts of other jurisdictions. In fact, some of these countries are taking such steps already. In Section IV, we use some recent technical decisions by the three authorities regarding mergers and anticompetitive practices to illustrate the application of economic tools to antitrust cases.

\section{A. Competition Law Framework in Argentina, Brazil, and Mexico}

\section{Argentina}

Argentina's enabling statute is its 1980 Law 22,262, which was subsequently modified in 1999 with Law 25,156. The 1980 law was largely based on Articles 85 and 86 (now Articles 101 and 102 TFEU) of European Union's Treaty of Rome, thus prohibiting price fixing agreements (cartels) and banning abuse of dominance (unilateral practices). ${ }^{10}$ Merger control was not introduced until 1999 with the new law.

9 See The Commission of European Communities, "Case No IV/M.1524 - Airtours/First Choice," (Sept. 1999), available at

http://ec.europa.eu/competition/mergers/cases/decisions/m1524_en.pdf.

10 Inter-American Development Bank, Organisation for Economic Co-operation and Development, Competition Law and Policy in Argentina: A Peer Review, OECD COUNTRY STUDIES (2006), available at http://www.oecd.org/daf/competition/Argentina-

CompetitionLawPolicy.pdf. 
This law created the National Commission for the Defense of Competition, under the jurisdiction of the Ministry of Commerce and International Economic Negotiations, which subsequently rendered a final decision. The 1999 law created an autonomous National Tribunal for the Defense of Competition with the authority to resolve cases and impose remedies and fines; the Tribunal has not yet been created.

Meanwhile, all decisions by administrative authorities can be challenged before courts in the federal system. Most appeals are heard before the Federal Civil and Commercial Court of Appeals in Buenos Aires, which is a quasi-specialized court, but not specialized in competition matters. ${ }^{11}$ Its decisions can be further appealed to the Supreme Court. Although the legal system does not create binding precedent, cases decided by the courts, especially the Supreme Court, do have practical effects on antitrust decisions.

\section{Brazil}

Brazil's first competition law was enacted in 1962 (Law 4137-62). The law was subsequently reformed in 1994 (Law 8884/94) and more recently in 2011 (Law 12,529/12). ${ }^{12}$ The new statute considers violations of the law cartels (article 36 , paragraph 3 ), and various unilateral and concerted actions (also within the purview of article 36), noting more generally that any actions which limit or restrict competition, control markets, arbitrarily increase profits, or constitute an abuse dominant position are economic violations under the law. The law prohibits mergers that eliminate competition in a substantial portion of the relevant market or that enhance a position of dominance in a relevant market. The biggest change in the new law relates to merger review. The previous law had language that would apparently require all agreements, not just mergers, to be reviewed; this is clarified under the new law, which also streamlines review

\footnotetext{
${ }^{11}$ The court has competency to resolve cases related in commercial matters and has decided various competition cases. However, the Supreme Court has intervened in some so that it is still unclear whether this court has indeed competence to review all competition-related cases, hence the term quasi-specialized that we use here. See Jorge Otamendi, Tribunales competentes en material de aplicación de la ley de defense de la competencia, LA LEY 2006C, 656-DERECHO COMERCIAL DOCTRINAS ESENCIALES, TOMO V, 505, available at http://www.gbreuer.com.ar/admin/files/boletin_archivos/Tribunales\%20competentes.pdf.

12 Brazil National Law 12, 529/12 (2011), available at http://www.cade.gov.br/Default.aspx?84a467a9769494b68e.
} 
procedures and updates thresholds (Title VII, Chapter I, articles 8891). ${ }^{13}$

In Brazil, the law that created the current competition authority, the Administrative Council for Economic Defense (CADE), was enacted before the 1990s. The 1962 Law 4137/62 created CADE and up until 2011, CADE shared competition enforcement responsibilities with the Secretariat of Economic Law of the Ministry of Justice (SDE) and the Secretariat for Economic Monitoring of the Ministry of Finance (SEAE). The new law establishes that the Brazilian Competition Defense System is made up of CADE and SEAE. ${ }^{14}$ It transfers SDE's investigative and preliminary enforcement responsibilities to a new CADE Superintendent, and terminates SEAE's advisory role in conduct and merger investigations. The new law grants CADE judicial powers and makes it a federal agency that depends on the Ministry of Justice, but continues SEAE's competition advocacy responsibilities.

An internal appeal exists before CADE's Plenary and is then appealed before courts. Courts are a significant source of delay in CADE's decisions. Federal courts of first instance hear appeals, with a second appeal from regional courts of appeals and then the Supreme Court of Justice. Cases involving claims of unconstitutionality may be appealed beyond the Superior Court of Justice to the Supreme Federal Court. Even though judges are not obligated to follow higher court decisions, they have begun to do so. Generally, the merits of the decisions are currently left to specialized tribunals such as CADE.

\section{Mexico}

Mexico's first prohibition of monopoly comes from its 1857 Constitution. ${ }^{15}$ With no legislation to make this prohibition effective, competition policy did not really exist until 1993, when it was adopted

\footnotetext{
13 Description based on Inter-American Development Bank, Organisation for Economic Cooperation and Development, Competition Law and Policy in Brazil: A Peer Review, OECD COUNTRY STUDIES (2010), available at

http://www.oecd.org/daf/competition/45154362.pdf.

14 Id., Article 3.

15 Constitución Política de la República Mexicana de 185xConstitution of the Republic of Mexico of 1857), art. 28, available at http://www.juridicas.unam.mx/infjur/leg/conshist/pdf/1857.pdf. "There will be no monopolies or state monopolies of any kind, nor prohibitions aimed at protection of industry. Excepted only those relating to the coinage of money, to the privileges that, for a limited time, the law grants to inventors or improvers for some improvement."
} 
as part of the conditions for the signing of the North American Free Trade Agreement (NAFTA). The Federal Law for Economic Competition (LFCE), ${ }^{16}$ largely inspired by US statutes, has been praised for its simplicity and breadth by the OECD in its 2004 review, ${ }^{17}$ but it has proven to be difficult to understand for courts and practitioners, because of the widespread use of economic concepts throughout it. The law divides conduct into two types: those that ought to be reviewed under a per se standard, and those that ought to be reviewed under a rule of reason standard. Cartels lie in the first category ("absolute monopolistic practices"), and all other conduct that must be analyzed under a rule of reason standard-including unilateral conduct-under the second type ("relative monopolistic practices"). Merger review was also included in the original law, with thresholds pegged to minimum wages to ensure that these are in line with current economic conditions.

The law created the Federal Competition Commission (CFC) as a technically autonomous agency, dependent in its budget on the Ministry of the Economy. It is responsible for enforcing the law and has other attributions outside the LFCE and noted under laws in regulated sectors, mainly overseeing competition conditions in regulated sectors that, if absent, may trigger price regulation imposed by sectoral regulators. It can also give binding opinions in certain public tender processes and administrative bills, which can only be overturned by a Presidential veto.

During its initial years the CFC's decisions were subjected to an avalanche of appeals before the courts. Economic agents not only appealed decisions, but also every single administrative act through district judges, appellate tribunals, and the Supreme Court. In its decisions, the courts have made clear that the use of economic terminology in the law is constitutional. To strengthen the CFC, there have been two reforms to the law, in 2006 and 2011, mostly granting the CFC additional powers, streamlining its merger procedures, allowing for a leniency program (to incentivize self-reporting of violations), and increased fines for violations. Another round of

\footnotetext{
16 The enabling law, bylaws, internal code of rules as well as court jurisprudence legal statute are available at Comisión Federal de Competencia México, Compendio Normativo en Materia de Competencia Económica, (2012), available at

www.cfc.gob.mx/images/stories/Leyes/compendionormativo/2012/compendiocfc_2012_ octubre.pdf.

17 Inter-American Development Bank, Organisation for Economic Co-operation and Development, Competition Law and Policy in Mexico: An OECD Peer Review (2004), available at http://www.oecd.org/mexico/31430869.pdf.
} 
reforms are currently under discussion to increase the powers of the CFC.

\section{B. Market Definition and Market Power}

\section{Argentina}

While the law makes no specific mention of relevant market definition, Article 5 identifies three factors to be considered in determining the existence of market power: the degree of substitution of the product or service (including the possibility of substituting with imports, the conditions for substitution and the time required to substitute); legal barriers to access these substitute goods by consumers or suppliers; and the ability of a seller to unilaterally influence prices. These factors should be considered in both merger and unilateral conduct cases. The guidelines issued for merger analysis (Resolution 164/2001) describe relevant market and power determinations. These are official guidelines, binding on the authority in merger cases. While not required in unilateral conduct cases, the guidelines are usually followed by agencies, especially when other guidance does not exist.

Resolution 164/2001 notes that the product market includes those goods and/or services that are substitutes based on characteristics, prices, and consumption purpose. Substitutes are those goods that capture the demand of a consumer, and should therefore be included in the same market. While the guidelines include the SSNIP test as a valid methodology for determining relevant market, it notes that the test is not conclusive to relevant market determination. The guidelines consider the possibility that price could be higher than marginal costs due to high fixed or sunk costs and takes into account characteristics other than price to determine demand substitution, such as additional services supplied by the company. None of these statements would contradict or negate the competitive constraints analysis that we discussed previously.

\section{Brazil}

While the law makes no explicit mention of how to define relevant markets, it states that dominance is presumed when a company or group of companies wields more than $20 \%$ of a relevant market (but grants discretion to CADE to modify this threshold for specific sectors). Thus, market shares are a hard boundary in the analysis of both mergers and unilateral conduct, making market definition a critical step in the process. 
CADE has mentioned, but never formally adopted the Horizontal Merger Guidelines issued by SDE and SEAE in 2001. ${ }^{18}$ The guidelines mention elements for the definition of a relevant market-including undertaking a hypothetical monopolist test-and the need to evaluate the probability of exercising market power-with a safe harbor of up to $20 \%$ market share and a measure of the participation of the four largest firms $\left(\mathrm{C}_{4}\right)$, below $75 \%$, or up to a $10 \%$ market share and a $\mathrm{C}_{4}$, above $75 \%$. Thus, the guidelines posit a traditional or formalistic merger analysis, which would require a clearly defined relevant market where market shares could be determined, and an identification of economic agents and their joint shares in the market (at least the four largest) ${ }^{19}$ Nonetheless, CADE, who as we mentioned has not formally adopted these guidelines to date, has noted in its resolutions the importance of considering competitive constraints, noting that firms that are followed or observed by other suppliers and by consumers in their negotiations to determine prices and establish commercial conditions, must be included in the relevant market. ${ }^{20}$

\section{Mexico}

In Mexico, market definition is a legal prerequisite for a finding of harm-in the case of abuse of dominance or monopolization claims (relative monopolistic practices under Mexican law)-and a requirement for a finding of potential harm-in the case of mergers, the analysis of public tenders, and determinations of effective competition conditions in regulated sectors. ${ }^{21}$ As such, market definition and power determinations must reach hard boundaries, including estimating or considering market shares before any decision is taken requiring this analysis.

According to statute, a market definition analysis must examine substitution possibilities, (article 12, paragraph I); transportation costs for the relevant product, its inputs, complements, and

18 Joint Directive SEAE/SDE No. 50 (Aug. 1, 2001), available at http://www.cade.gov.br/internacional/Horizontal_Merger_Guidelines.pdf.

19 The guidelines also mention the "hypothetical monopolist test," also part of a traditional or formalistic merger analysis.

${ }^{20}$ See Resolution 15/98, available at http://www.cfc.gob.mx/docs/pdf/ra-15-98.pdf.

21 See Directorate for Financial and Enterprise Affairs Competition Committee, Roundtable on Market Definition, OECD (2012), available at

$\mathrm{http}: / /$ search.oecd.org/officialdocuments/displaydocumentpdf/?cote=DAF/COMP(2012)1 3\&doclanguage $=$ en . 
substitutes to determine the relevant geographic market (article 12, paragraph II); users' possibilities of switching to alternative product or service offerings-to a large extent a re-statement of substitution possibilities-(article 12, paragraph III); and barriers to entry or expansion (article 12, paragraph IV). For market power determination the law requires that the authority "consider" market shares and the economic agent's ability to fix prices unilaterally (article 13, paragraph I); barriers to entry (article 13, paragraph II); the existence and power of rivals (article 13, paragraph III); access to inputs (article 13, paragraph IV); recent behavior (article 13, V); and other criteria established in the bylaws.

The statute, while imposing strict requirements on any analysis (e.g. market share "consideration"), does not establish thresholds or methodologies, noting only that there must be a finding of harm. In mergers, harm is described as those mergers "whose objective or effect is to reduce, harm or prevent competition and free market access of products and services that are equal, similar or substantially related . . ." these are prohibited. In conduct investigations, harmful actions are those "... whose object or effect is or may be to unduly displace other agents from the market, substantially foreclose their access, or establish exclusive advantages in favor of one or more persons ..." Because the law is silent about possible methodologies for relevant market and market power determination, the authority has some flexibility to use new or different analytical tools to support its conclusions and eventual decisions.

An increased awareness of the need for methodological guidance recently led the CFC to commission white papers on market definition and market power. The reference documents are intended to be used for any procedures that require this analysis, not just mergers. The previous section draws largely from these two white papers. ${ }^{22}$

\section{Summary}

While all three authorities incorporate elements of a formalistic approach in their legislations, including the need to calculate market shares (Mexico), and even safe harbors (Brazil and Argentina), they also require (Argentina) or suggest (Brazil) the use of the hypothetical monopolist test, and mention minimum elements that need to be accounted for in market definition analysis, such as substitution, and in market power determination, for example barriers. We summarize

${ }^{22}$ See Market Power Report and Market Definition Report. 
and compare the flexibility in each country's legal framework to accommodate different technical elements in their analysis of markets and power in the following table.

\section{Table 1: Market Definition and Market Power Determination in Latin America.}

\begin{tabular}{|lccc|}
\hline & Argentina & Brazil & Mexico \\
\hline Relevant market: definition in law or jurisprudence? & $?$ & $?$ & $\checkmark$ \\
Product and geographic dimension & $\checkmark^{23}$ & $\checkmark^{24}$ & $\checkmark$ \\
Hypothetical monopolist test (SSNIP) & $?^{26}$ & $\times$ \\
\hline Targeted customers/discrimination & $?^{27}$ & $?^{28}$ & $\checkmark^{29}$ \\
\hline Location of suppliers & $\checkmark^{30}$ & $\checkmark^{31}$ & $\times$ \\
\hline
\end{tabular}

23 Secretaría de la Competencia, la Desregulación y la Defensa del Consumidor (Secretary of Competition, Regulation, and Consumer Defense), Resolution 164/2001, available at http://www.infoleg.gob.ar/infolegInternet/anexos/70000-74999/70302/norma.htm.

24 Joint Directive, SEAE/SDE No. 50 (2001) at 8, available at http://www.cade.gov.br/internacional/Horizontal_Merger_Guidelines.pdf. Product and geographic dimension of the relevant market are defined in Item 28.

25 Resolution 164/2001, available at http://www.infoleg.gob.ar/infolegInternet/anexos/70000-74999/70302/norma.htm. Note that this test is not conclusive.

${ }^{26}$ Joint Directive, SEAE/SDE No. 50 (2001) at 8, available at http://www.cade.gov.br/internacional/Horizontal_Merger_Guidelines.pdf. The SSNIP test is defined in Item 30 of the Guidelines of Horizontal Mergers but is not used often in the analysis of cases.

${ }^{27}$ While not explicitly mentioned, Resolution 164/2001 does not prohibit it either.

${ }^{28}$ It is not explicitly described in law, Guidelines or cases.

${ }^{29}$ See Market Definition Report, which is a suggested set of best practices but non-binding to the authority.

$3^{\circ}$ Resolution 164/2001, available at http://www.infoleg.gob.ar/infolegInternet/anexos/70000-74999/70302/norma.htm. It is important to analyze the producers' location for the determination of the relevant geographic market.

${ }^{31}$ Joint Directive, SEAE/SDE No. 50 (2001) at 9, available at http://www.cade.gov.br/internacional/Horizontal_Merger_Guidelines.pdf. Item 32 of the Guidelines for horizontal concentrations describes that the agency must consider suppliers' location, but this is not always included in the analysis of all cases. 


\begin{tabular}{lcccc}
\hline & Argentina & Brazil & Mexico \\
\hline Location of consumers & $\sqrt{32}^{32}$ & $\checkmark^{33}$ & $\checkmark$ \\
Supply-side substitution & $\sqrt{34}$ & $\checkmark$ & $\checkmark^{35}$ \\
\hline Market power: definition in law or jurisprudence? & $\checkmark$ & $\checkmark$ & $\checkmark$ \\
\hline Market participants/rapid entrants & $\checkmark{ }^{37}$ & $\checkmark$ & $\checkmark$ \\
Market shares & $\checkmark^{38}$ & $\checkmark$ & $\checkmark$ \\
Market concentration & $\sqrt{ }^{39}$ & $\checkmark$ & $\checkmark$ \\
\hline Supply-side substitution & $\sqrt{40}^{40}$ & $?$ & $?$ \\
Marginal consumers & $?^{41}$ & $?^{42}$ & $\checkmark^{43}$ \\
\hline
\end{tabular}

$3^{2}$ Resolution 164/2001 requires evidence that consumers are able to move to other areas due to changes in price in order to buy the product.

33 Joint Directive, SEAE/SDE No. 50 (2001) at 9, available at http://www.cade.gov.br/internacional/Horizontal_Merger_Guidelines.pdf. Item 32 of the Guidelines for horizontal concentrations notes that the agency must consider consumers' location, but this is not always considered in every case.

34 Resolution 164/2001 can be interpreted as saying both that rapid entrants need to be considered (a low barriers to entry argument) and that supply-side substitution ought to be included as well, since the example it presents is that of paper whereby a company can adjust its production technology to produce different grades of paper.

35 Joint Directive, SEAE/SDE No. 50/2001 at 9, available at http://www.cade.gov.br/internacional/Horizontal_Merger_Guidelines.pdf. According to Item 32 of the Guidelines for horizontal concentrations, the agency must consider time and costs involved in producing substitute products, but this is not always included in all of the cases analyzed.

${ }^{36}$ By allowing for technical possibilities of substitution of a product or service within paragraph I of article 12, the law is allowing for supply-side substitution within the relevant market definition analysis. Federal Law of Economic Competition, Mexico.

37 Resolution 164/2001, available at http://www.infoleg.gob.ar/infolegInternet/anexos/70000-74999/70302/norma.htm.

$3^{8}$ Resolution 164/2001, subsection II.3 (and is also applied where concentrations are horizontal or vertical).

39 Resolution 164/2001, subsection II.4 (and in several cases when the type of concentration is horizontal or vertical).

${ }^{40}$ Resolution 164/2001, subsection IV. Consider supply side substitution as an element for the possibility of abusing market power.

${ }^{41}$ Although not explicitly excluded, marginal consumers' considerations are not taken into account neither in the Resolution 164/2001 nor in case decisions. 


\begin{tabular}{|c|c|c|c|}
\hline & Argentina & Brazil & Mexico \\
\hline Non-price competition: innovation and product variety & $?^{44}$ & $\checkmark$ & $\sqrt{45}$ \\
\hline Buyer power & $\eta^{46}$ & $?$ & 47 \\
\hline Entry (timely, likely, sufficient) & $\checkmark^{48}$ & $\sqrt{ }^{49}$ & $\checkmark 50^{\cdots}$ \\
\hline Efficiencies & $\sqrt{51}$ & $\checkmark$ & $\checkmark$ \\
\hline Competitive assessment: definition in law or & $?^{--}$ & $?^{52}$ & $\checkmark^{53}$ \\
\hline
\end{tabular}

42 Marginal consumers are not considered in law or in the Guidelines for Horizontal Mergers. They are not considered either in the cases analyzed, but this type of analysis is not prohibited.

\section{Market Power Report at 13-14.}

44 Resolution 164/2001 subsection III.b. Non-price competition, mainly innovation, is considered as part of the unilateral effects to measure the competitive assessments, but is not mentioned with regards to market power.

\section{Market Power Report; Market Definition Report.}

46 Is not explicitly defined in Resolution $168 / 2001$ but an outline of this subject could be seen in subsection VI, and in various cases vertical relations of parties to a concentration, where upstream and downstream effects are analyzed and the agency has explores any changes to buying power.

47 Market Power Report, 16-17.

${ }_{48}$ Resolution 168/2001, Subsection IV.

49 Horizontal Merger Guidelines, Item 45, available at http://www.cade.gov.br/internacional/Horizontal_Merger_Guidelines.pdf.

${ }^{50}$ Article 12 of rulings to the law (Federal Law of Economic Competition, Mexico) describes different elements that can be considered barriers to entry, such as financial costs, investment amounts and indivisibilities, legal barriers, advertising expenditures and legal limitations, but does not explicitly describe timeliness, likeliness and sufficiency of entry.

${ }^{51}$ Resolution 168/2001, Subsection VI.

$5^{2}$ Horizontal Merger Guidelines, Items 61-65, available at http://www.cade.gov.br/internacional/Horizontal_Merger_Guidelines.pdf.

53 This is contained within the definition of relative monopolistic practices-conduct analyzed by rule of reason (article 10)-and of anticompetitive mergers (article 16). The language for both note that in order to establish an infringement to the law it is necessary to determine that their objective or effect is to unduly displace, substantially foreclose or establish exclusive advantages, for conduct investigations; or to reduce, harm or impede competition and free market access for anticompetitive mergers. Federal Law of Economic Competition, Mexico. 


\begin{tabular}{lccc}
\hline & Argentina & Brazil & Mexico \\
\hline jurisprudence? & & & \\
Unilateral effects & $\checkmark^{54}$ & $\checkmark$ & $\checkmark$ \\
Coordinated effects & $\checkmark^{55}$ & $\checkmark$ & $?^{56}$ \\
\hline
\end{tabular}

Table 1 suggests a consensus about the goals and elements required for market definition and determination of market power, with other elements still to be defined as the case law and practice evolve. There is sufficient latitude in the legal frameworks of these three jurisdictions to determine competitive constraints. In our view, nothing in the legal framework prevents competition agencies in these countries from conducting the correct economic analysis.

Nonetheless, as the next section discusses, internet-based industries exhibit traits that make economic analysis more complex relative to other industries and which, if ignored, can lead to incorrect conclusions. We discuss some of the principles that ought to be considered in defining markets and analyzing market power for online businesses, largely based on the idea that many of these firms are in fact rivals for users' attention. ${ }^{57}$ To illustrate the importance of competitive constraints in the analysis of markets and power in internet-based industries we use the Microsoft/Skype decision, which illustrates the types of questions that ought to be posed and answered by an authority when investigating anticompetitive practices or mergers in these industries-we do not, of course, mean to judge this decision as a whole. A more recent case, which also undertook this

54 Resolution 164/2001. Unilateral effects are not explicitly stated as such, but the Resolution states that a merger review must consider whether the company eliminated was a vigorous and effective competitor.

55 Resolution 164/2001. Coordinated effects are not explicitly stated as such, but the Resolution states that the characteristics of the remaining competitors in the relevant market have to be considered, and if they tend to accept stability and behave as followers, competitive conditions could be harmed.

${ }^{56}$ Federal Law of Economic Competition, Mexico. This is still an open question. Article 17 of the law clearly foresees unilateral effects but adds that any act or attempt to exercise monopolistic practices is evidence of an anticompetitive merger. This has currently been interpreted as a possibility to review coordinated effects within a merger.

57 This section draws largely from David S. Evans, Attention Rivalry among Online Platforms and Its Implications for Antitrust Analysis, JOURNAL OF COMPETITION LAW AND ECONOMICs (forthcoming). University of Chicago Institute for Law \& Economics Olin Research Paper No. 627 (2013), available at http://dx.doi.org/10.2139/ssrn.2195340. 
type of analysis, is the decision by the High People's Court in China in the matter of Qihoo $v$. Tencent. The Court in this matter concluded that Tencent did not have a dominant position partly because it competed against several other platforms that attracted traffic by using different products and services and led to profits from the sale of advertising and value-added services. ${ }^{58}$

\section{INTERNET-BASED INDUSTRIES}

\section{A. The Development of Online Industries}

The online industry has resulted from the evolution of two related technologies, the World Wide Web and the development of mobile telecommunications. The first, the Web, consists of pages that people can see with a browser and accessed over the Internet. Internet-based industries, however, now transcend products and services offered and accessed through these pages only, as they increasingly include offline products and services among their offerings, e.g. Amazon.com competes with brick and mortar stores, Google Drive competes with Microsoft's Windows/Office offerings; in fact there are traditional appliances that are now controlled over the internet (thermostats, washer and dryers).

Up until recently webpages were primarily accessed using personal computers. This is no longer the case, which leads us to the second major development of the World Wide Web: the development of mobile communications. Most people in the world have a mobile phone that they can use over domestic wireless networks. A steadily increasing fraction of those users have "smart mobile devices" which enable them to access the Internet. Those devices are computers with operating systems that support mobile applications and browsers. Both developments have spurred the creation of businesses, or extensions of existing businesses, that rely on these online technologies. These online businesses conduct many of their activities "in the cloud"-collections of server computers that are accessed through the Internet.

The development of the Internet has led to the creation of an "online world" of commerce and community. The development of smart mobile phones has resulted in the deep penetration of the online world through the day and across physical location. The result is that increasingly the Internet is always on, everywhere. 
Importantly, the development of smart mobile phones is spurring the growth of online industries in developing and lesser-developed economies because it lowers the cost of access significantly to a large portion of people and businesses.

Today, and looking forward, the online and offline worlds are merging. Internet connectivity over wireless is being integrated into more devices such as point-of-sale devices for merchants, cars, and televisions. Moreover, an increasing number of people carry during their movement through the physical world smart mobile phones with location-based technologies that enable Internet-connected applications to know where users are. The result of this is that many physical activities, including shopping, are integrating online aspects.

Despite the fact that the development of the commercial Internet happened almost two decades ago there remains rapid growth and innovation. In the United States, for example, which has one of the most advanced online industries, online commerce still accounts for only 5 percent of total commerce. There is a common misconceptionknown as the "end of history illusion"-that we have seen all the change there is and that the most recent revolution is the last, this illusion recurs whenever we face a major technological change or drastic innovation. It is useful to keep this illusion in mind in considering market definition for the online world. Six years ago-but more than a decade after the rise of the commercial Internet-smart phones, social networking, and micro-blogging were insignificant activities. Six years hence it would appear likely that there will be new activities as disruptive as these.

Before we begin our analysis of competitive constraints for online businesses it is useful to survey the current state of development of these businesses in Latin America and the three countries that we are focused on. Most Latin American countries have a vibrant Internetsector with many consumers engaging in online activities. As a general matter e-commerce is not as highly developed in most Latin American countries as it is in the US and most of the EU countries. Nevertheless, there are certain similarities; about 25 percent of the time spent online in the region involves using social networks compared with 29 percent in the US. Table 2 summarizes key aspects of Internet use in Argentina, Brazil, and Mexico. We have also provided comparisons to the US. Obviously, the use of the Internet in Latin America also shows significant differences between major cities and outlying areas. 
Table 2: Summary of Internet Use in Argentina, Brazil, and Mexico

\begin{tabular}{lccc}
\hline Key metric & Argentina & Brazil & Mexico \\
\hline $\begin{array}{l}\text { Broadband } \\
\text { penetration }(\% \text { of } \\
\text { households) }\end{array}$ & $12.6 \%$ & $6.4 \%$ & $11 \%$ \\
$\begin{array}{l}\text { Average time } \\
\text { using Internet per }\end{array}$ & 26.1 hours & 27 hours & 26.7 hours \\
$\begin{array}{l}\text { month } \\
\text { Percent of } \\
\begin{array}{l}\text { population that } \\
\text { uses the Internet }\end{array}\end{array}$ & $24 \%$ & $11 \%$ & $14 \%$ \\
$\begin{array}{l}\text { Percent of people } \\
\text { with smart } \\
\text { phones }\end{array}$ & $24 \%$ & $14 \%$ & $20 \%$ \\
\hline
\end{tabular}

While there are differences in infrastructure build-up (broadband penetration) and even in device ownership (percent of people with smart phones), it is interesting to note that the one variable where all three countries have similar numbers is the average time they spend each month using the Internet, regardless of the means by which they are accessing it, which is roughly 26 hours. This reflects a fairly hard constraint-all Internet-based firms must compete for a share of the total amount of time users spend using the Internet. We call this "competition for scarce attention" and discuss it in more detail below. ${ }^{6} 3$

59 Lucia Bibolini and Lawrence Baker, Latin American Broadband and Internet Market, 9th ed., available at http://www.budde.com.au/Research/2010-Latin-AmericanBroadband-and-Internet-Market.html.

${ }^{60}$ Comscore, available at http://www.comscore.com (last accessed Dec. 2011).

61 Comscore, available at http://www.comscore.com (last accessed June 2007).

62 Google and Ipsos, 2012, available at

http://www.rcrwireless.com/americas/20120522/devices/smartphone-penetration-24-inargentina-20-in-mexico-14-in-brazil.

${ }^{63}$ The advent of smart mobile devices has increased the amount of time that consumers realistically have available for Internet-based activities. They are still constrained by having no more than 168 hours a week. 


\section{B. Basic Economics of Online Industries}

There are several aspects of online businesses that can affect the competitive constraints that online businesses face.

\section{Multi-Sided Platforms}

Many online businesses are multi-sided platforms that serve as intermediaries-or in some way connect-two or more distinct groups of customers. ${ }^{64}$ The most common situation involves properties that connect consumers with merchants. Some of these properties attract consumers with content and then present advertisements that help merchants obtain sales. Others provide online malls that create a place for consumers to shop and merchants to sell online. Other platforms attract users and support application developers. Many of those application developers in turn connect consumers and merchants. Like many multi-sided platforms, online platforms often provide services to one side of the platform at no charge (the "subsidy side") and make money from the other side (the "money side").

Multi-sided platforms often have indirect network effects. Users on one side of the platform value having a larger number of users on the other side of the platform. That creates a start-up problem because platforms need to have a critical mass of customers on both sides to be viable. An online mall is not valuable to shoppers unless there are enough merchants, and is not valuable to merchants unless there are enough shoppers. That also creates an engine for growth. Once a platform reaches critical mass, more users on one side may entice more users on the other side; these sorts of positive feedback effects can fuel growth.

In the early days of the Internet, some commentators argued that positive feedback effects would result in first-movers attaining monopolies. In fact, as we will see below reality has been much more complicated than that. Many investors who bet on the positive feedback strategy as the road to monopoly and riches were wiped out in the dot.com crash of 2001. As we will see below, churn has largely characterized these industries, not just during a stock market crash, and this includes those firms who arrived first to market and who were regarded as unseatable.

\footnotetext{
64 See David S. Evans and Richard Schmalensee, The Antitrust Analysis of Multi-Sided Platform Businesse, OXFORD HANDBOOK ON INTERNATTONAL ANTITRUST ECONOMICS, eds. Roger Blair and Daniel Sokal (Oxford University Press, 2013). Also available in UNTVERSITY OF CHICAGO INSTITUTE FOR LAW \& ECONOMICS, Olin Research Paper No. 623 (forthcoming), available at http://ssrn.com/abstract $=\mathbf{2 1 8 5 3 7 3}$.
} 


\section{Technology}

Online businesses rely almost entirely on software that runs in the cloud. That software could be a sophisticated platform such as Facebook, or it could be a simple web site designed to display content. As a result, these businesses typically involve a fixed cost for developing the software ${ }^{65}$ and a low marginal cost for people accessing that software. This software can support third-party developers by exposing Application Programming Interfaces (APIs) and providing other services; that is, the software becomes a multi-sided software platform. ${ }^{6}$

The underlying software and IT technology for online businesses has two implications. At least in terms of the physical infrastructure for the business the cost of entry is relatively low. It is possible to start and grow rapidly with a programmer and rented server space. It is also relatively easy-since it involves writing code-to change and add features to the products and services being offered. And once those changes and features are added it is possible to make them available to all customers instantly. Thus, online businesses are very different from physical businesses and particularly manufacturing businesses.

\section{Competition for Scarce Attention}

Many online businesses seek the attention of consumers and then make that attention available to advertisers, merchants, developers, and others. That attention, however, is a scarce commodity. People only have so much attention since they have to sleep, work, and do various other things that cannot be done offline. This scarcity creates intense competition among online businesses to get that attention. It is the main driver behind innovation as businesses try to develop something new to attract attention. Competition among these online attention rivals is the principal focus of the remainder of this section because they constitute the preponderance of online activity and shape the dynamics of much online competition.

We focus on evidence from the United States in much of this discussion since it is one of the more advanced online markets and therefore provides a harbinger of developments for Latin America. There is also systematic data over long periods of time available in the

\footnotetext{
${ }_{5}$ The fixed cost could be endogenous in the sense that firms invest more in the asset in anticipation of attracting more people.

${ }^{66}$ See David S. Evans, Andrei Hagiu, and Richard Schmalensee, Invisible Engines: How Software Platforms Drive Innovation and Transform Industries (MIT Press, 2006).
} 
US to assess dynamic competition, which may not always be readily available even for the largest or more advanced Latin American economies, which we have studied here. Whenever possible, we will provide similar information for Argentina, Brazil, and/or Mexico or for the region as a whole.

\section{Attention Rivalry}

People only have so much time-precisely 168 hours a week. That time gets parceled out to various activities involving work, leisure, and sleep. Increases in activities that one can do online can draw time away from other activities that comprise this fixed time constraint for consumers. However, that substitution becomes harder to do since it is difficult for consumers to curtail activities such as work, sleep, and various leisure activities.

\section{Evidence on Competition for Scarce Attention}

In fact, in the United States the amount of time the average Internet user spent online doubled between 2001 and 2010. ${ }^{67}$ But the number of distinct web servers increased six fold in part because of the entry of new web properties and the expansion of those properties. The amount of content likely increased more than six fold since those servers were able to handle an increasing amount of capacity as memory prices declined. Therefore, the amount of online content increased far more rapidly than the amount of attention available for that content.

A study for the US conducted by Evans found that of the top 15,000 websites in September 2002, 12,775 (85 percent) had fewer hours spent by visitors in September 2012 than in September 2002. ${ }^{68}$ Furthermore, 14,036 (94 percent) increased the total time spent by less than the 373 percent increase in the overall time spent on websites, and therefore had declining shares of attention. Even with the total time spent by internet users on the web increasing by nearly a factor of five over this period, the 85 percent of attention losing

\footnotetext{
${ }^{67}$ David S. Evans, Attention Rivalry among Online Platforms and Its Implications for Antitrust Analysis, UNIVERSITY OF CHICAGO INSTITUTE FOR LAW \& ECONOMICS OLIN, Research Paper No. 627 (2013) at 9-10, available at http://ssrn.com/abstract $=2195340$ or http://dx.doi.org/10.2139/ssrn.2195340. The total amount of time spent online increased by 373 percent between September 2002 and September 2012. That figure includes both the increase in the number of people online and the increase in the average amount of time spent online.
}

68 Id. 
websites in the top 15,000 in September 2002, managed to lose a total of 460 million of hours by September 2012. These 460 million hours represent 30 percent of the total number of hours spent on all websites in September 2002.

A further analysis suggested that, over the decade, consumers shifted not just between websites in the same category, such as playing games online, but between different categories. In particular the share of the amount of time spent on portals (including search) declined from 68 percent in 2002 to 28 percent in 2012 while the share of time spent on social networking increased from 2 percent in 2002 to 29 percent in 2012.

There is one important point to note on the scarcity of attention. The development of smart mobile phones resulted in a discrete jump in the attention available for online activities. That is because people can use mobile devices throughout the day and engage in multitasking with them in ways that they could not do as conveniently with computers. That jump occurred in the late 2000 s as people started acquiring the new iPhone and then Android-based phones. The trend is continuing as more people acquire these and other smart mobile phones and tablets.

\section{Competition for Seeking Attention}

Attention rivals see each other as competitors. As Yahoo! observed, "[w]e also compete with social media and networking sites which are attracting a substantial and increasing share of users and users' online time, and may continue to attract an increasing share of online advertising dollars." ${ }^{369}$ A review of financial filings by leading web properties found that many of them identify other properties that provide very different products and services as rivals. ${ }^{70}$ What these properties all have in common is that they are seeking attention from consumers and are trying to make money by selling that attention to retailers or programmers.

In this part we examine the competitive constraints they impose on each other for seeking attention and in the next for providing attention.

\footnotetext{
69 United States Securities and Exchange Commission, Yahoo Inc. Annual Fiscal Report (Washington D.C. 2011) at 14, available at http://www.sec.gov/Archives/edgar/data/1011006/000119312513085111/d442073d10k.ht m.

${ }^{\circ 0}$ See Evans, Attention Rivalry.
} 


\section{a. Scarcity of Attention}

Consumer attention is an input into selling advertising, sales services, and other services. It is scarce because consumers have a limited amount of time available and because a minute spent on one website is a minute less available for another website. As with any scarce input, firms must compete vigorously in order to attain it. The pursuit of attention sets up the basic dynamic of much online competition.

On this basis, competition occurs among very different offerings of site content, such as: search sites, social networking, social media, portals, auction sites, newspapers, entertainment, multimedia, games, etc. In Table 3 we show the different types of competition that websites competing for advertise are facing.

Table 3. Ranking of types of websites in the selected countries by Total Minutes stayed at the site. ${ }^{71}$

\begin{tabular}{|c|c|c|c|c|}
\hline \multirow[t]{2}{*}{ Type of site } & Argentina & Mexico & \multicolumn{2}{|c|}{ Brazil } \\
\hline & 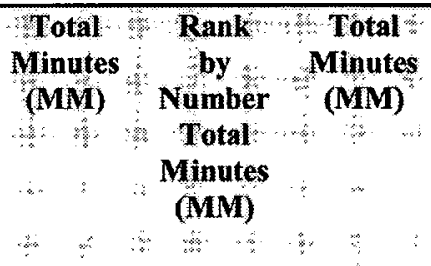 & $\begin{array}{l}\text { Rank } \\
\text { by } \\
\text { Number } \\
\text { Total } \\
\text { Minutes } \\
\text { (MM) }\end{array}$ & $\begin{array}{c}\text { Total } \\
\text { Minutes } \\
\text { (MM) }\end{array}$ & $\begin{array}{c}\text { Rank } \\
\text { by } \\
\text { Number } \\
\text { Total } \\
\text { Minutes } \\
\text { (MM) }\end{array}$ \\
\hline Social Media & 10,203 & 1 & 52,863 & 1 \\
\hline Social Networking & $7,852 \quad 2 \quad \therefore 9,960$ & 2 & 49,386 & $\therefore$ \\
\hline Corporate Presence & 3,702 & 3 & 23,128 & 4 \\
\hline Entertainment & 2,823 & 4 & 17,000 & 6 \\
\hline Services & 4,547 & 5 & 18,665 & 5 \\
\hline Multimedia & 1,911 & 6 & 9,641 & 7 \\
\hline News/Information & 1,864 & 11 & 3,225 & 12 \\
\hline Portals & 1,617 & 7 & 27,073 & 3 \\
\hline e-mail & 1,080 & 8 & 6,700 & 8 \\
\hline Promotional Servers & 714 & 10 & 5,454 & 9 \\
\hline Games & 675 & 12 & 4,202 & 10 \\
\hline
\end{tabular}

${ }^{71}$ Comscore, available at http://www.comscore.com (last accessed Apr. 2013). 


\begin{tabular}{lcccccc|}
\hline General News & 623 & 12 & 234 & 25 & 2,192 & 17 \\
Newspapers & 618 & 13 & 306 & 20 & 731 & 33 \\
\hline Search/Navigation & 523 & 14 & 936 & 9 & 3,525 & 11 \\
XXX Adult & 508 & 15 & 703 & 13 & 2,650 & 16 \\
\hline Online Gaming & 502 & 16 & 487 & 16 & 3,086 & 14 \\
Retail & 422 & 17 & 489 & 15 & 3,136 & 13 \\
\hline Sports & 421 & 18 & 292 & 22 & 1,802 & 20 \\
\hline Directories/Resources & 323 & 19 & 568 & 14 & 1,704 & 22 \\
\hline Lifestyles & 294 & 20 & 439 & 17 & 1,439 & 26 \\
\hline
\end{tabular}

It is interesting to note that time spent is not overwhelmingly concentrated in one or a couple of websites. If we estimate a Herfindahl Hirschman Index (HHI) for these 20 attention grabbers in Latin America (based on Argentina's top 20) the HHI's for Argentina, Mexico, and Brazil are 1,220 1,198 and 1,308 respectively-figures that denote relatively unconcentrated markets. Concentration is overestimated with this measure as it excludes all other websites that do not make the top 20-it assumes they have a zero share of the market for consumers' web minutes.

\section{b. Pricing for Securing Attention}

Attention seekers typically do not charge consumers for visiting their online properties and in fact entice them to come to their sites, and spend time there, with valuable services. This practice is similar to that of many multi-sided platforms that make access free, or indeed subsidize, one group of consumers. They do that, as is the case with attention seekers, in part because that group of consumers is highly valuable to the other side. In the case of attention rivals, it is especially not surprising that consumers get services for free given that there is intense competition for scarce attention.

\section{c. Feature Competition}

Given a price of zero, attention seekers primarily compete for attention by offering new attractive features. That constant feature competition is particularly apparent to users of smart mobile devices. Many times over the space of the year users are prompted to update their applications often as a result of the addition of new features. Feature competition is rapid and pervasive among attention seekers in part because of how they attract new customers and keep existing ones engaged. Consumers have come to expect that online businesses will do this and that their online businesses must introduce new 
features regularly to remain competitive. Importantly, a website can add a new feature and all of its users all around the world can immediately have access to it.

\section{d. Drastic Innovation}

In addition to feature competition, there is "drastic innovation" which creates completely new and highly trafficked categories. Examples of these over the last decade include Facebook, Pinterest, Twitter, Wikipedia, and YouTube. These websites brought new products and services in the market previously not even in the consumer's imagination.

\section{e. Entry, Exit, and Churn}

There is frequent entry by advertising-supported online attention seekers. These range from small businesses such as blogs to ones that become large quickly such as Twitter. As the study by Evans documented for the US, each month, Compete.com reports the top 15,000 websites by unique visitors. Out of the top 15,000 websites in the January 2012 list, 3,954 (26 percent) were replaced by different websites on the July 2012 list, just six months later. ${ }^{72}$ Many of these new entrants quickly grew to a substantial size. The largest 100 of them each had more than 150,000 hours of time, which would have placed them in the top sixth of the January 2012 list. $^{73}$ Over a longer time period, out of the 15,000 websites in the September 2002 list, 12,257 ( 82 percent) were replaced by different websites on the September 2012 list, a full ten years later. ${ }^{74}$ As a consequence of this growth, the number of very large websites is growing. Table 4 shows the growth in the number of websites with more than one million hours of attention per month.

\footnotetext{
${ }^{2}$ Some of these new websites do not represent new businesses, but are rather new websites for existing businesses.
}

73 Compete.com database, January 2012 and July 2012.

74 Compete.com, September 2002 to September 2012. 
Table 4: Growth in the Number of Websites Attracting Large Amounts of Time Spent in the US.75

\begin{tabular}{|c|c|c|c|}
\hline & \multicolumn{3}{|c|}{ Number of Websites Exceeding Threshold } \\
\hline $\begin{array}{c}\text { Threshold } \\
\text { (Hours Per } \\
\text { Month) }\end{array}$ & September 2002 & September 2007 & $\begin{array}{c}\text { September } \\
2012\end{array}$ \\
\hline $\mathbf{1 , 0 0 0 , 0 0 0}$ & 95 & 224 & 453 \\
\hline $\mathbf{2 , 0 0 0 , 0 0 0}$ & 37 & 101 & 231 \\
\hline $\mathbf{5 , 0 0 0 , 0 0 0}$ & 16 & 38 & 89 \\
\hline $\mathbf{1 0 , 0 0 0 , 0 0 0}$ & 8 & 17 & 44 \\
\hline $\mathbf{2 0 , 0 0 0 , 0 0 0}$ & 4 & 9 & 21 \\
\hline
\end{tabular}

We see this churn in Latin America as well. Tables 5-7 show the change in the rankings of websites between 2006 and 2013 measured by number of visits, based on data from Alexa for our three study countries. ${ }^{76}$ In each country many top websites fall out of the top ranking and other websites increase or decrease their standing.

Table 5: Top 20 Websites Visited in Argentina in 2006 and 2013.

\begin{tabular}{|l|c|c|}
\hline Web Site & Rank 2006 & Rank 2013 \\
\hline Google Argentina & 1 & 2 \\
\hline Live.com & 2 & 5 \\
\hline Fotolog.net & 3 & \\
\hline Youtube & 4 & 3 \\
\hline Yahoo! & 5 & 7 \\
\hline MSN & 6 & 15 \\
\hline El Clarin & 7 & 12 \\
\hline MercadoLibre Argentina & 8 & 6 \\
\hline Facebook & 9 & 1 \\
\hline Taringa! & 10 & 8 \\
\hline Google & 11 & 4 \\
\hline Blogger.com & 12 & - \\
\hline metroFLOG & 13 & - \\
\hline
\end{tabular}

75 Compete.com, September 2002, September 2007, and September 2012.

${ }^{76}$ www.alexa.com. 


\begin{tabular}{|l|c|c|}
\hline Web Site & Rank 2006 & Rank 2013 \\
\hline Rapidshare & 14 & - \\
\hline Wikipedia & 15 & 10 \\
\hline Poringa.net & 16 & - \\
\hline Google España & 17 & - \\
\hline Microsoft.com & 18 & - \\
\hline La Nacion & 19 & 11 \\
\hline Sonico.com & - & - \\
\hline Twitter.com & - & 9 \\
\hline Infobae & - & 13 \\
\hline Babylon & - & 14 \\
\hline Linkedin & - & 16 \\
\hline Ole & - & 18 \\
\hline Xvideos & - & 19 \\
\hline Ask & & 20 \\
\hline Wordpress & & \\
\hline
\end{tabular}

Table 6: Top 20 Websites Visited in Brazil in 2006 and 2013.

\begin{tabular}{|l|c|c|}
\hline Web Site & Rank 2006 & Rank 2013 \\
\hline Orkut Brasil & 1 & - \\
\hline Google Brasil & 2 & 2 \\
\hline Live.com & 3 & 6 \\
\hline UOL & 4 & 5 \\
\hline YouTube & 5 & 4 \\
\hline Yahoo! & 6 & 9 \\
\hline Globo.com & 8 & 7 \\
\hline Google & 9 & 3 \\
\hline Terra Brasil & 10 & 12 \\
\hline MSN & 11 & 16 \\
\hline Blogger & 13 & 14 \\
\hline IG Noticias & 10 \\
\hline MercadoLivre & & 10 \\
\hline
\end{tabular}




\begin{tabular}{|l|c|c|}
\hline Web Site & Rank 2006 & Rank 2013 \\
\hline Rapidshare.com & 14 & - \\
\hline Orkut & 15 & - \\
\hline Wikipedia & 16 & 11 \\
\hline 4shared.com & 17 & - \\
\hline Microsoft & 18 & - \\
\hline Easyshare & 19 & - \\
\hline Wordpress & 20 & 20 \\
\hline Facebook & - & 1 \\
\hline Twitter & - & 13 \\
\hline Babylon & - & 15 \\
\hline Abril & - & 17 \\
\hline Banco Itau & - & 18 \\
\hline Linkedin & - & 19 \\
\hline
\end{tabular}

Table 7: Top 20 Websites Visited in Mexico in 2006 and 2013.

\begin{tabular}{|l|c|c|}
\hline Web Site & Rank 2006 & Rank 2013 \\
\hline Google Mexico & 1 & 2 \\
\hline Live.com & 2 & 5 \\
\hline Youtube & 4 & - \\
\hline metroFLOG & 5 & 9 \\
\hline MSN & 6 & 6 \\
\hline Yahoo! & 7 & \\
\hline Hi5 & 9 & 4 \\
\hline Google & 10 & 8 \\
\hline Wikipedia & 11 & - \\
\hline Mercadolibre & 12 & - \\
\hline Blogger & 13 & - \\
\hline RapidShare & 14 & 1 \\
\hline MySpace & 15 & - \\
\hline Facebook & 16 & - \\
\hline Fotolog.net & & - \\
\hline Microsoft & & \\
\hline
\end{tabular}




\begin{tabular}{|l|c|c|}
\hline Web Site & Rank 2006 & Rank 2013 \\
\hline Wordpress & 17 & 15 \\
\hline Google España & 18 & - \\
\hline PhotoBucket & 19 & - \\
\hline Sonico & 20 & - \\
\hline Twitter & - & 7 \\
\hline Babylon & - & 11 \\
\hline Amazon & - & 12 \\
\hline Xvideos & - & 13 \\
\hline Linkedin & - & 14 \\
\hline El Universal & - & 16 \\
\hline Taringa! & - & 17 \\
\hline Ask & - & 18 \\
\hline Bing & & 19 \\
\hline Tumblr & & 20 \\
\hline
\end{tabular}

\section{f. Number of Competitors}

Thousands of firms compete for consumer attention in this way on the Internet. Of the top 500 websites in the US as measured by time spent, 135 primarily gather attention and sell it to advertisers, defined narrowly. The HHI for these websites is $1345^{-a}$ figure denoting a relatively un-concentrated market-based on time on site and assuming zero share for websites outside of the top 500; as a result of the zero share assumption, this HHI is therefore overstated. The five largest sellers of attention have 67 percent of the attention garnered by these 135 websites. Defined slightly more broadly, 233 of the top 500 websites primarily gather attention and sell it to advertisers. ${ }^{77}$ The HHI for these websites is 1088 , again assuming a zero share for

\footnotetext{
77 Under the narrower definition, a website counts as an advertising-supported attention seeker if 1 ) it is consumer-focused, and 2) its revenues come exclusively or almost exclusively from banner ads, search ads, or flat listing fees for items for sale. Under the broader definition, a website counts as an attention-seeker if 1) it is consumer focused, 2) it earns substantial revenue from banner ads, search ads, fees for items for sales (whether flat listing fees, commissions, revenue sharing, buyer fees, or sales lead fees), 3 ) its other revenue comes from advertising-related sources, such as consumer research, marketing campaign design, other marketing services, premium membership fees for consumers to avoid ads and/or receive additional services, and credits for virtual goods.
} 
websites outside of the top 500. The five largest attention sellers have 60 percent of the attention garnered by these 233 websites. Attention seeking is not a winner-take-all business.

\section{Competition for Providing Attention}

In this part we focus on attention rivals that earn revenue by selling attention to advertisers. We comment on the relevance of this to offline attention rivals that provide other commerce-related services at the end of this section. Online attention rivals are similar to traditional advertising-supported media platforms such as newspapers, magazines, and television. They provide news and entertainment to attract viewers and then sell display-advertising spots on their pages. However, because they are software-based media properties, these attention rivals can engage in highly targeted advertising that is customized to the person viewing the advertisement.

Online advertising-supported attention rivals sell many different kinds of advertising. These include search-based, social media, and display advertising. The advertisements themselves range from short text ads to image-heavy display ads to video ads. Some, primarily display ads, are sold based on the number of people who see the ads, while others are sold based on whether individuals click on the ads. Most online advertising is targeted based on information, or educated guesses, about the person looking at the screen at a particular point in time.

Advertisers buy online advertising because they want to sell products and services to consumers-to obtain what are called "conversions." They therefore make decisions on how much to spend on advertising and how to allocate that spending across different advertising channels-offline as well as online-by comparing the rate of return on incremental investment across different channels. Historically, advertisers have faced challenges in making these decisions rigorously because of lack of data on the relationship between advertising spending and conversions. They have had to make them judgmentally based on a mixture of subjective and objective information.

In recent years, however, advertisers have started using sophisticated software-known as cross-channel attribution technologies-for determining the marginal return on investment of

${ }^{78}$ Conversions are defined as the proportion of visitors to a website who take action to go beyond a casual content view or website visit as a result of subtle or direct request from marketers, advertisers, and content creators. 
expenditures on different channels. ${ }^{79}$ These technologies collect data on who has seen various ads, match that data to information on whether there was a sale, assess the importance of different ads in generating that sale and in some cases provide dynamic reallocations of advertising budgets across sales channels based on results. ${ }^{80} \mathrm{~A}$ survey of 607 entities in late 2011 found that 77 percent of advertising agencies and 62 percent of markets used these technologies. ${ }^{81}$ A study of 53 marketers examined how they used cross-channel attribution technologies. ${ }^{82}$ Virtually all of them used it to "measure the value and performance of digital channels" (98 percent). Almost two thirds (64 percent) "use attribution to make improvements to in-flight or future interactive marketing strategies like channel allocation and media planning optimization." They used these attribution technologies to examine many different channels. More than 70 percent of the markets said they considered paid search, online display, natural search, affiliate partners and email. More than a third also considered Facebook posts, comparison shopping engines, Twitter, online video ads, and the brand's own website.

The existence and widespread use of cross-channel marketing technologies shows that advertisers (or advertising and marketing firms which serve as their agents) see different online channels as substitutes. Otherwise they would not be using products that facilitate

79 See Catherine Tucker, The Implications of Improved Attribution and Measurability for Online Advertising Markets?, (Competition Conference, University of Melbourne, Nov. 6, 2012), available at

http://ipria.org.au/events/conf/Competition_Conference/Measureabiltiy_and_online_ad s.pdf.

80 According to marketing material for Visual IQ's IQ Intelligence Suite, which is one of the leading cross-channel attribution technologies, "Once your marketing performance data and customer data (and any other data you wish to include) has been collected, formatted, normalized and integrated during the software set-up process, IQ Insight presents it to you through its powerful, yet easy to use dashboard and reporting interface. This allows you the flexibility to view, report upon and compare the performance of every channel, campaign and marketing tactic side by side, and to analyze that performance by any criteria specific to your company, industry or business model. IQ Insight provides both executive overview and granular views of your marketing ecosystem using a common set of your own key performance indicators (KPIs)," available at http://www.visualiq.com/products/iqintelligence-suite (last accessed Nov. 2012).

81 Econsultancy (2012). The data were collected from September 26 through October 23, 2011. Of 607 respondents, 44 percent were located in North America and 33 percent were in the United Kingdom.

82 Forrester Interactive Attribution (2012). 
the comparison of their marginal returns on investment. The availability and widespread use of these technologies also makes it likely that these different channels have relatively high degrees of substitution. Advertisers compare them using a single metric and can make quick adjustments to their campaigns depending on the rates of return, which depend on costs and results. In fact, the survey of 607 marketers and agencies in the US and UK discussed above found that users of channel-attribution technologies changed their spending as result of their use of these technologies. As shown in Figure 2, responses from 179 of those surveyed shows that they appeared to have substituted between both online media as well as between online and offline media.

Figure 2: Substitution between Advertising Channels

$\therefore$ Signiticant increase a Some increase $=$ No change a Some decrease $;$ Significant decrease

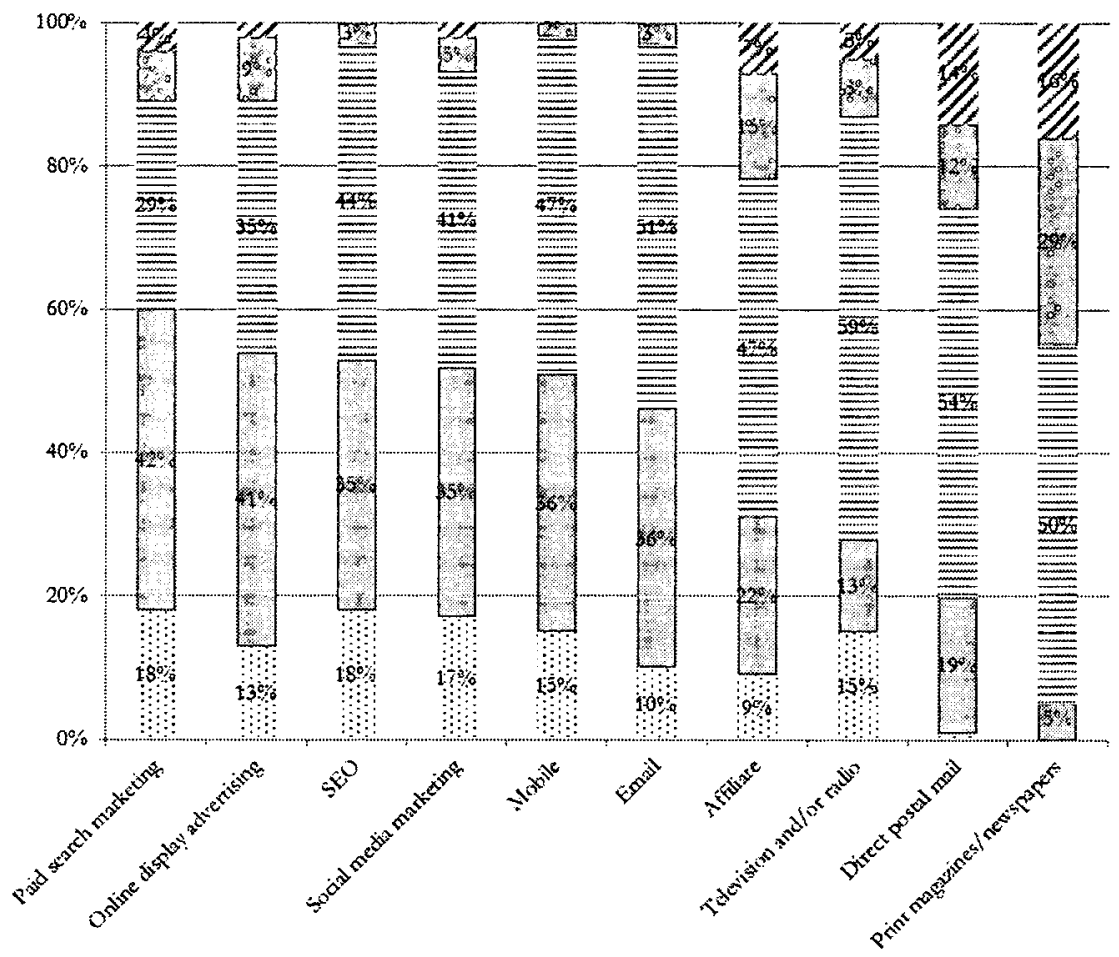




\section{Product Differentiation and Attention Seeking}

Attention rivals are obviously dramatically different from each other. Twitter provides a very different service to viewers (microblogging) than Yahoo! (content curation). Twitter also provides a very different service to advertisers-tweets with short urls for links-than Yahoo!-multi-color display ads. The point of this section, however, is that those differences are not necessarily relevant for assessing competition among online businesses. These attention rivals are all competing aggressively with each other to secure attention. The emergence of Twitter likely took viewers away from Yahoo!. And the fact that services like Twitter can become quickly established and grow explosively puts constant pressure on attention seekers. These attention rivals then compete for advertisers to buy access to some of that attention. But advertisers are constantly looking for ways to reallocate their budgets among different channels to get what they often really want-a sale. They do not necessarily care whether that sale came from a tweet, a search, a social network ad, or a variety of other media.

This section does not claim that attention rivals are necessarily all in the same market. As usual with competition policy analysis we need to consider the facts. Those facts may show product differentiation among platforms softens competition enough to make the relevant antitrust market narrower than "all attention rivals." But differentiation is not functional equivalence, meaning that companies ought to offer services with equivalent functions in order to be considered competitors. Indeed, this is exactly the point we argue against in section I of this paper. As our previous example of Yahoo! and Twitter illustrates, the fact that ads in one firm are displayed and look different than they do in the other, does not mean that the entry of one rival into the market (Twitter) cannot divert marginal consumers from one firm to the other-going back to our best practices lexicon-and therefore can effectively constrain competition for Yahoo!

In contrast, we could consider that there are enough facts to determine that one attention rival does not share the same market as another. There could be differences among the people providing attention. An advertiser seeking to sell an expensive automobile is interested in getting the attention of high-income people who are likely in the market for buying a car. The attention of a teenage game player is not a substitute. Hence the importance of garnering information about customers by age and income group; for example, in 2006, in Mexico 58\% of internet users were between 12-24 years old, $34 \%$ were between $25-44$ years old, and $8 \%$ were more than 45 
years old; in $2010,50 \%$ of internet users were between 12-24 years old, $29 \%$ were between $25-44$ years old, and $11 \%$ were more than 44 years old ${ }^{83}$ There could also be differences in the manner in which attention is generated which in turn reduces substitution possibilities. The value of messages that are delivered on a search results page, as a display advertisement on a web page, or as part of a web-based video could differ. There are differences in the formats that are dictated in part by the method of producing the attention. The context in which the attention is generated could also lead to differences in the value of attention to advertisers. Such product differentiation could result in some attention seekers, or some segments of attention seekers, having significant market power. ${ }^{84}$

There are several factors, however, that tend to reduce the importance of differentiation for online platforms. Physical media often have differentiated content because this tends to attract particular types of consumers who are attractive to particular advertisers, alternatively this type of media may also bundle content in the hope of attracting a widest possible audience who will select the content they find appealing. In the case of online media, software and data-based targeting technologies can be used to identify particular kinds of consumers without the need to bundle and differentiate their content to a wide audience in order to engage the "right" audience. They are therefore less reliant on content differentiation for targeting

\footnotetext{
${ }_{33}$ Asociación Mexicana de Televisión (AMIPCI), Hábitos de los usuarios de Internet en Mexico. May 17, 2011 and October 2007, 2011 version available at http://www.slideshare.net/venturis/amipci-hbitos-de-los-usuarios-de-internet-en-mxico2011.

84 Different sources of attention may have different values to advertisers because of differences in "how attentive" people are to advertisements on the property and the context in which they are seeing the advertisements. These differences between source of attention lead to differences in the likelihood that a view by a consumer will result in a "conversion"-that is a sale of a good-for the merchant. However, these differences do not necessarily lead to traditional product differentiation issues. For example, if property A leads to 10 percent of the conversions per person viewing an advertisement as property $B$, and that is the only difference, the price for showing an ad to a person on property $B$ would be 10 percent of the price of the same advertisement on property $A$. At these prices the two properties would be close substitutes. For example, it is much "cheaper" per click to buy display ads on Facebook than to buy search ads on Google. But the Facebook ads result in much fewer conversions per click than do the Google ads. See Larry Kim, Google Display Network vs. Facebook Advertising, WORDSTREAM (2012), available at http://www.wordstream.com/blog/ws/2012/o5/15/ipo-facebook-vs-google-displayadvertising; see also, JCD Repair, Google Adwords us. Facebook Ads - It Was No Contest, (2012), available at http://www.jcdrepair.com/blog/google-adwords-vs-facebook-ads-itwas-no-contest/645.
} 
the right people. It is also easier for online attention rivals to reposition themselves in the event that there is a market opportunity in another niche. They can add features, including content, to attract particular consumers.

\section{Extensions of Offline Attention Seekers}

There are reasonable arguments for why different types of offline attention seekers do not compete with each other. Consider offline advertising-supported platforms. Historically advertisers did not have good data for comparing the effectiveness of television, radio, and print advertising. Their budgeting and allocation decisions were therefore highly judgmental. These media were different from each other and therefore arguably served different advertising purposes. Entry and expansion was much harder than it is for online advertising. It would also be hard to argue that advertising-supported platforms were close substitutes for commerce platforms such as shopping malls, if for no other reason than the time cost and inconvenience of travel.

The emergence of online advertising and development of sophisticated technologies has changed this in several ways. The fact that it is possible to measure and determine incremental returns of investment for online attention seeking places pressure to consider the same issues for offline attention seeking. Knowing the return on investment (ROI) for online display advertising encourages advertisers to think through the likely ROI for offline advertising to make budgeting decisions. In addition, the development of computer technologies has made it increasingly possible to measure conversions in physical advertising-such as using coupon codes in print advertising.

As noted above, some of the cross-channel attribution technologies compare online with offline advertising channels. Figure 2 showed that this comparison has encouraged substitution particularly away from print and towards online. Goldfarb and Tucker have also found evidence of substitution between online and offline advertising. ${ }^{85}$ The online and offline worlds for commerce are converging and this is likely to increase the degree of substitution. The use of mobile devices is bringing the online world into physical spaces.

$8_{5}$ Avi Goldfarb and Catherine Tucker, Substitution between Offline and Online Advertising Markets (2010), available at http://dx.doi.org/10.2139/ssrn.1721001. 
Advertisers and marketers are using increasingly mobile applications to drive physical commerce. ${ }^{86}$

\section{The Analysis of Market Definition and Market Power}

This section has argued that "attention"-its acquisition and its delivery-is the relevant dimension for analyzing the competitive constraints these rivals impose on each other. ${ }^{87}$ In practice, attention rivals more frequently face significant competition from purveyors of new products or services that could divert consumer attention from them, than from the entry of close substitutes for their existing products or services. Ostensibly different attention rivals often substitute for each other from the standpoint of consumers and merchants. Product differentiation tempers the significance of these constraints. Product differentiation is relevant, however, when it involves aspects of the attention that is procured and sold, rather than particular features of the products and services used for acquiring and delivering that attention to advertisers.

Antitrust analysis should therefore focus on competition for securing and delivering attention in considering market definition, market power, and competitive effects. Focusing on competition between specific products and services, rather than attention, could result in competition authorities and courts making either falsenegative or false-positive errors in their decisions. False-negative errors could result from concluding that attention rivals do not compete because they offer dissimilar products or services. False positive errors could follow from ignoring competition among attention rivals that offer different products and services. Analyzing attention, which is the dimension on which these rivals compete in fact, reduces the likelihood of these errors. The precise contours of

\footnotetext{
${ }^{86}$ Chantal Tode, Macy's makes mobile integral part of Black Friday strategy to drive instore sales, Mobile Commerce Daily (2012), available at http://www.mobilecommercedaily.com/macy\%E2\%80\%99s-enhances-mobile-app-tofacilitate-shopping-on-black-friday; Chantal Tode, Fairmont Hotels enhances foursquare check-ins with location-based offers, Mobile Commerce Daily (2012), available at http://www.mobilecommercedaily.com/fairmont-hotels-enhances-foursquare-check-inswith-location-based-offers.

87 For the purposes of this Article, attention is the time that consumers spend focusing their minds on content. Attention rivals provide products and services to buyers, such as advertisers, who would like to get some of this attention. This attention is not necessarily fungible. Depending on the circumstances in which it is provided advertisers might have a chance of getting more attention or greater focused from consumers or might get attention in a context that makes that attention more valuable because they have a greater chance of persuading consumers to buy something.
} 
markets, market power, and impacts on competition will depend on the particular circumstances of the subjects of the antitrust analysis, the conduct under consideration, and the extent of differentiation among relevant attention rivals.

There is no doubt that the Internet has resulted in the emergence of large global firms that lead their categories. To take a few examples, Facebook is clearly the leader in social networking, Google in search, and Twitter in micro-blogging. However, as we have shown, several factors need to be considered in evaluating whether these entities have long-lived market power and whether product or services categories correspond to relevant antitrust markets:

- The product or services categories morph quickly and easily. Google has moved into social networking, Facebook into search, and Apple into advertising-supported media;

- There is rapid displacement of leaders both overall and within categories. Facebook very quickly displaced Google as the most trafficked web property globally-it took a little longer, however, to displace Brazil's social networking site, Orkut-and Apple displaced Blackberry as the software development platform for mobile devices, with Google, through its Android platform, now contending strongly for this market; and

- The Internet-based industry is highly dynamic with frequent drastic innovation, a feature that is consistently mentioned in best practice relevant market and market power determination as difficult to analyze within a traditional, hypothetical monopolist or structuralist approach to do it right. Every time we think the online industry has reached maturity, disruptive innovation changes it all.

Attention rivals impose competitive constraints on each other across boundaries defined by products and services they provide to consumers and advertisers. It is an empirical matter whether these 
constraints are strong enough to place particular attention rivals in the same relevant antitrust market and to significantly limit the market power of particular platforms. This will ultimately depend, in part, on the extent to which consumers and advertisers turn from one attention seeker to another as prices, quality, and features change. Some standard tools of competition analysis-diversion analysis and econometric analysis of demand, adjusted for applicability to multisided platforms - can help analysts obtain the evidence necessary for a proper assessment. We offer here the example of relevant questions that the European authority posed in reviewing the merger between Skype and Microsoft. Our next section offers examples of how Argentina, Brazil, and Mexico have posed similar such questions, which follow the best practices we outlined, to reach an informed conclusion on cases which unfortunately have not yet been about Internet-based industries.

As we noted at the outset of this paper, what is important in assessing market definition and market power is a careful analysis of competitive constraints rather than formalistic methods that do not correspond to economic realities. A good example of these principles involves the EU's analysis of Microsoft's proposed acquisition of Skype ${ }^{88}$ The European Commission's decision approving Microsoft's acquisition of Skype echoes many of the themes we have discussed above. Skype is an Internet-based company. It provides software that enables people to communicate over the Internet through instant messaging, voice calls, and video calls. Microsoft agreed to acquire Skype in 2011 for $\$ 8.5$ billion. Among other things Microsoft also has an Internet-based communication service call "Windows Live Messenger" (WLM). ${ }^{89}$ The combination would result in Microsoft having an 80-90 percent share of video calls in the European Economic Area (EEA). Yet the European Commission considered the possible effects of the merger and approved it without conditions. $9^{\circ}$

\footnotetext{
${ }^{88}$ Although an example from one of the three Latin American countries we have presented here would have been ideal, our research into the experiences of Argentina, Brazil, and Mexico in reviewing internet-based cases offered very little information about their analysis. Nevertheless, we present a summary of this research in an Appendix to the paper.

${ }^{89}$ Skype and Microsoft provide communication services to consumers and enterprises. For the sake of brevity this section just considers the merger issues relevant for the consumer services.
}

90 EC Microsoft Skype Decision, Case No. Comp/M.6281-Microsoft/Skype (2011) at 20, available at

http://ec.europa.eu/competition/mergers/cases/decisions/m6281_20111007_20310_207 9398_EN.pdf. 
The Commission recognized the ease of entry into web-based businesses and how quickly these new businesses could grow:

- “... the use of sites such as Facebook, Google+, LinkedIn, and Twitter has more than doubled since January 2009."

- "The Commission observes several recent entries into the consumer communications services markets. The example of Viber Media ... shows that it is possible even for a small company to enter the market and attract a significant number of users within a short period of time."

- "The Commission notes that IM is a dynamic market, as illustrated by the fast growth of Facebook that has become the leader for IM in less than three years with a market share of approximately $50 \% . "$

- “... smaller players have succeeded in rapidly entering, and gaining traction in the consumer communications sector with innovative products."

In addition, it noted that existing firms innovate and add new features constantly.

- "The innovation cycles in these markets are short. As a result, software and platforms are constantly being redeveloped. Innovators generally enjoy a short lead in the market."

This innovation is important because feature competition is important.

- "Since consumer communications services are mainly provided for free, consumers pay more attention to other features. Quality is therefore a significant parameter of competition." 
- "Consumers are very sensitive to innovative services or products in consumer communications services. Providers ... lose traction quickly if they are unable to offer users new and innovative functionality. For example, Skype's innovations over the last eight years highlight the critical role innovation plays in its success...."

The Internet-based communication providers are also price takers.

- "These markets, and this is also true for video calls, are currently free of charge. If a company were to charge for its service, competitors would switch to alternative providers offering their service free of charge. This is confirmed by internal documents of Skype showing that [ $>75 \%$ ] of its users would switch to an alternative provider if Skype started charging for its free service (in particular for video calls)."

The Commission declined to define communication markets based on functionality given the ease with which consumers could switch between different services. And, while it also declined to define specific markets, its decision to approve the merger is clearly based on finding that ease of entry, feature competition, price-taking behavior, and rapid innovation defeated the exercise of market power. Despite finding that Microsoft would obtain a dominant position in video calling it approved the acquisition without conditions. In doing so it specifically relied on evidence that the providers are price-takers and would lose customers if they did not compete on feature innovation.

\section{TECHNICAL CAPACITY: ARE AUTHORITIES READY?}

Throughout this paper we have underscored the need to look at competitive constraints in assessing markets and power. We've included some examples of key competitive factors, and have noted that some of these are particularly relevant for internet-based industries such as the possibility of using multiple devices to access similar content-including mobile devices-(multihoming), the speed of innovation, and the importance that seeking and providing attention plays for firms in this market. The analysis of Internet-based 
industries has a degree of complexity that is not always present in more traditional industries, which begs the question of whether Latin American competition agencies are equipped to undertake them.

In this section we use non-Internet cases reviewed or investigated by each of the three authorities to illustrate how they have in fact undertaken complex analyses and have used the best practices in market definition and power that we've outlined. We also include as a general reference, a compendium of historical cases that do involve Internet-based industries. To date, none of the Internet cases have used the complex analysis to which we have referred to before.

\section{A. Competitive Constraints Analysis in Practice: Selected Case Studies}

\section{Argentina}

In December 2004, Telefónica Móviles S.A. announced the acquisition of the assets of BellSouth Corporation. In Argentina, Grupo Telefónica was one of the two main suppliers of fixed telephony services, and one of the four main suppliers of mobile telephony services. BellSouth, also one of the four main suppliers of mobile telephony services, had minor market shares in other telecommunications activities including data transmission, Internet, cable television, and long distance fixed telephony. At the time, the CNDC identified seven markets where both companies were active and evaluated the likely effects of the merger over the competitive dynamics of the market, as well as potential vertical effects derived from the concentration. ${ }^{91}$

Although a traditional market share analysis was undertaken considering participation prior to and following the merger, the authority observed that between 2001 and 2004, the market shares of the participants had varied. Hence, it considered that the intensity of the competition in the market was high, given the volatility of the market shares. Furthermore, it reasoned that competitors would be in a position to respond to any potential increases in price from the merged company, as they possessed enough spectrum to increase their service offerings and offset any exercise of market power by the merged company. Lastly, the Commission considered that although spectrum accumulation by itself can determine competitive conditions in the telecommunication industry, accumulation can also lead to efficiencies in the market due to reductions in marginal and total cost.

91 National Commission for Defense of Competition (CNDC), Dictámen 196/2004, Grupo Telefónica and BellSouth Corporation (2004). 


\section{Brazil}

The operation involved an agreement between Nestlé and Garoto Brasil in which Nestlé would acquire new stocks issued by Garoto. Considering the market of chocolates as a whole, Nestlé was the leading company, alternating the first place with Kraft Foods (Lacta), with Garoto as the third largest firm. Nestlés average market share between 1998 and 2001 was of $34.5 \%$, while Garoto's was $23 \% .{ }^{92}$

The merging parties and Kraft filed dueling market definition studies, employing price elasticity models to estimate consumer reactions to relative prices among different chocolate formats and chocolate brands. Because results were dramatically different CADE was forced to consider a host of methodology issues associated with simulation models, including identification of the relevant demand function, assessment of the statistical uncertainty associated with demand elasticity estimates, and examination of the potential defects in the differentiated products models that the simulations employed.

Other hotly contested issues included barriers to entry and the prospects for expansion of such rival brands as Mars and Hershey. The Council studied the minimum efficient scale required to enter the market, the time required for entry to be effective, minimum investments required to enter and selling possibilities. CADE concluded it was unlikely that Kraft would make investments necessary to offset market power. This conclusion together with the difficulty of entry into the market led CADE to conclude that the probabilities that the merged firm would abuse its market power was high.

\section{Mexico}

The case involved a renewed complaint by Pepsi Bottling Group against Coca-Cola for exclusive dealings in the small retail shop distribution outlet, which comprised $70 \%$ of all sales in the industry and involved more than 1 million points of sale nationwide. This conduct was foreclosing the market for Pepsi's own carbonated beverages. $^{93}$

\footnotetext{
92 Ato de Concentração 08012.001697/2002-89. Ofício SDE/GAB 050/2002. Nestlé Brasil LTDA. e Chocolates Garoto S.A. (2002), available at http://www.cade.gov.br/Default.aspx?e142c252a3798dadb8.
}

93 Case number DE-013-2008 (appeal RA-037-2012), available at http://resoluciones.cfc.gob.mx/ (last accessed June 2012). 
The Federal Competition Commission (CFC) constructed a threestep structured rule of reason test to determine potential harm arising from the conduct. It considered that there was a high probability of harm if any of the following three conditions existed (a) if, under normal conditions, an entrant that is as efficient as a standard industry measure of efficiency cannot enter (does not reach a Minimum Efficient Scale or MES); or (b) if the conduct is prevalentthat is sufficiently widespread-such that it prevents industry participants from attaining "normal" levels of efficiency; and/or (c) if the conduct determines the incumbent's ability to maintain or increase its dominance.

The authority found that Pepsi was able to attain a MES and in some cases, was in fact operating in the decreasing returns to scale portion of its costs. Through a survey of depositions by store keepers offered as evidence by the complainant, it found the conduct was relatively infrequent (less than $4 \%$ of the small shops confirmed the exclusivity agreements) and had a short duration (less than 1 year). Finally, the CFC found that consumers have access to other products in the distribution channel; that there was a competitive dynamic in the market (entry, exit, innovation-new drinks, etc.); and that CocaCola's market power arose mostly from the value of its brand and the efficiency with which it operates its distribution network. The case was closed and the decision withstood an appeal before the Commission.

As evidenced by the three cases presented here, authorities have focused on competitive dynamics and non-price information when determining ex ante harm to competition (mergers) as well as ex post anticompetitive conduct (investigations). The case in Argentina illustrates how the CNDC recognized that shares were not a useful metric of market power when these are volatile and there are other dimensions for rivals to compete aggressively (e.g. spectrum). Brazil's case highlights the importance of evaluating diverse evidence to reach a determination, and to review evidence based on accepted economic methodologies that CADE determined in this case. It also illustrates the importance of including estimates of minimum efficient scale (MES) of entry when reviewing barriers to entry. MES played an important role in the decision by the Mexican authority also, as it determined whether foreclosure was indeed possible as an effect of exclusive deals. The Mexican case shows how market power should not focus solely on the level of market shares held by the defendant but on whether its conduct increases this level and causes harm. 


\section{B. Internet Analyses in Practice: Case Studies}

In order to give a broad perspective of the types of cases that the authorities have reviewed and the degree of complexity and depth that has so far been required in analyzing them, we present a selection of cases-the majority of them-that the CNDC, CADE, and the CFC have reviewed over a period of time that spans 2000 through 2009 . The fast pace of change in the industry is not only evident in the cases, but also in the agencies' decisions. In addition, since 2000-the first internet-based case we have on record-there have been important changes in the technical know-how and expertise within the agencies themselves, as they have garnered knowledge and experience, and have sought training for their employees. The cases are grouped into three different types of analyses. For example, a number of transactions involved vertical integration between Internet access providers and online content producers; others involved horizontal acquisitions either in the jurisdictions themselves or elsewhere but with effects in Latin American countries; some of these involved online businesses, others mergers of online and offline businesses. In each case, authorities seemed to be posing traditional questions to analyze a new industry. For vertical mergers, the acquisition of a website by an access provider focuses on an essential facility-type of query; for horizontal mergers, concerns seem more focused on whether content offerings or services are sufficiently similar to be considered substitutes or if these operations appear to be analogous to a company acquiring a portfolio of content. ${ }^{94}$

It is evident from the resolutions of the three authorities we included here, however, that they have been careful in not constraining themselves to set relevant market definitions or to strict methodologies for market power determination. It is particularly interesting to note the evolving description of Microsoft's business over the course of time as the Brazilian authorities analyzed the different merger deals, from a very generally defined market in 2001software development-to a broader conception of its business that goes beyond the IT industry: programming and correlated services for any customers involving online, business, and peripherals including entertainment. Yahoo! also conceives of its business as having a wider

94 It is unfortunate, however, that the level of detail in the analysis of these cases is scant in the case of Argentina and most notably in Mexico. Nevertheless, to the extent that we can present their decisions as a reference of what the agency considered the relevant markets to be and whether market power existed in this industry, we've included the authorities' determinations here. 
reach than just search capabilities or advertising revenues. Its business is no longer restricted to Internet, but includes features we associate with telecommunications and broadcasting markets, such as email, messaging, video streaming, and music. It is also interesting to highlight how Argentina's advertising market analysis tends to include all broadcasting distribution outlets: printed, video, streaming and internet media. In the case of Mexico, the information included in its case summaries points to a wide conception of the product market, again underscoring care in not overly constraining case law to narrowly defined markets in a rapidly changing industry.

\section{Offline and Online Mergers}

\section{a. AOL/Time Warner-Argentina}

In 2000, Argentina's CNDC analyzed the effects in its territory of the merger between America Online and Time Warner. ${ }^{95}$ The analysis does not suggest recognition that this was a two-sided market where market share analysis could provide little insight into market power; it also ignored any indirect externalities between each side of the respective offline and online content providers. Instead the agency's focus was on identifying overlaps between the two companies considering each side of the market as distinct. Thus, distribution of online and offline content was analyzed in two distinct channels: TV and Internet, finding no competition concerns. The CNDC also analyzed the other side of the market as a separate advertising market. This broad product dimension, led to a conclusions that the effects of the merger were very small as most advertising revenues did not come from pay TV or internet and were distributed as follows: coming from free to air TV (close to $40 \%$ ), newspapers (23\%), pay TV (12\%), and internet advertising at $0.1 \%$.

\section{b. Microsoft/aQuantive-Brazil}

In 2007, Microsoft sought to acquire aQuantive. ${ }^{96}$ aQuantive participated in the advertising sector through 3 business divisions: technology for digital publicity, digital communication performance,

\footnotetext{
95 CNDC, Dictamen 144, America Online Inc. and Time Warner Inc. (Oct. 24, 2000), available at http://www.cndc.gov.ar/dictamenes/39_1_000144.pdf.

96 Department of Justice, Secretary of Economic Law, Ato de Concentraçao 08012.008554/2007-11, Microsoft Corporation and aQuantive Inc. (2007), available at http://www.cade.gov.br/plenario/Sessao_404/Pareceres/ParecerProcade_AC_08012.00 8554-2007-11_001.pdf.
} 
and digital marketing. Microsoft described its business as creation, development, and provision of computer software and related services. Brazil's SDE considered that there was no horizontal overlap between the different companies, but noted that $90 \%$ of aQuantive's revenues came from Microsoft, so that the transaction had a vertical component. It consequently looked at the market offering online advertising services and found that there were a large number of competitors worldwide and therefore no evidence of upstream closure. The operation was approved.

\section{c. Microsoft/Fast Search-Brazil}

In 2008 Microsoft purchased all shares for Fast Search \& Transfer ASA, ${ }^{97}$ a Norwegian firm that developed and marketed software for corporate search. Microsoft described its business to the Brazilian authorities as a firm that participated in the market for operating systems, computer software and production of video, videogames, computer games, and other peripherals, as well as corporate search. The latter was the only market subject to analysis by SDE. SDE did not undertake a complete relevant market definition analysis as it considered that there were a large number of participants in the market, that Fast and Microsoft's participation was modest and that each party's service offerings were complementary. In addition, clients stated no opposition to the deal.

\section{d. Microsoft/Yahoo!-Brazil}

In 2009, Microsoft and Yahoo! decided on an exclusive licensing agreement for 10 years whereby Microsoft would grant Yahoo! technology to undertake algorithmic and sponsored searches. ${ }^{98}$ Following the 10 year period, the license would continue but with no exclusivity. Microsoft also agreed to offer advertising text services to Yahoo! and Yahoo! would become the sole worldwide representative of both companies in their sales relationship with premium advertisers. The agreement excluded web products, email services, instant messaging, graphic publicity, or other businesses. Microsoft's

\footnotetext{
97 Department of Justice, Secretary of Economic Law, Ato de Concentraçao 08012.000710/2008-78, Microsoft Corporation and Fast Search \& Transfer Asa. (2008), available at http://www.cade.gov.br/temp/t1010201310013648.pdf.
}

98 Department of Justice, Secretary of Economic Law, Ato de Concentraçao 08012.006419/2009-94, Ministério Da Justiça. Secretaria de Direito Econômico. Microsoft Corporation y Yahoo! Inc. (Aug. 24 2009), available at http://www.cade.gov.br/temp/t1010201310013966.pdf. 
programming and correlated services were described as including 5 segments: clients; suppliers and tools; online services; Microsoft business division; and accessories and entertainment division. Yahoo!'s services were divided into 6 categories: "Front Door" services (free to users and financed through advertisements); communities services; search services, also financed through advertising revenues; communication services; advertising and premium services, including TV and music services; and applications to access internet. Brazil's SDE defined online markets following previous jurisprudence, as global with an open geographic reach. SDE concluded that the deal would allow the parties to better compete with Google globally, and would improve advertising competition, benefiting those seeking to advertise, consumers, and improve websites.

\section{e. Yahoo!-Brazil}

There are two operations involving Yahoo! that the Brazilian competition agencies reviewed. The first in 2002 involved the acquisition of Starmedia, ${ }^{99}$ and was reviewed by all three Brazilian competition agencies. The second, involved the 2003 acquisition of Inktomi ${ }^{100}$ was also reviewed by the three agencies. In the first case Starmedia operated a Brazilian search engine named "Cade?" that edited and catalogued Brazilian websites. Both companies obtained revenues through advertising sales. Even though the advertising market could include TV, radio, printed media, and internet, $\mathrm{CADE}$ decided to take a narrow view of the market as internet advertising in Brazil, reasoning that it was a small but growing industry and data could not yet be secured to allow for a substitution analysis between "virtual" publicity and publicity in more traditional media outlets. Nevertheless, the transaction represented too small a market share to require further scrutiny. In the proposed acquisition of Inktomi Corporation by Yahoo! the authorities determined the relevant market to be internet search, where Yahoo! did not participate but purchased search technology from Google, who did compete with Yahoo! in offering website services. Although the authorities did foresee future vertical relations among the parties, they did not consider this to be a concern. In the case of the Brazilian authorities' analysis of Yahoo!'s

\footnotetext{
99 Department of Justice, Administrative Council for Economic Defense, Ato de Concentraçao 08012.000182/2002-61, Yahoo! Do Brasil Internet y Starmedia do Brasil Ltda.
}

100 Department of Justice, Secretary of Economic Law, Ato de Concentraçao 08012.000212/2003-11 Yahoo! Inc. y Inktomi Corporation (Jan. 14, 2003). 
acquisition of Starmedia as early as 2003, the small size of this market and lack of data to allow for a more in depth analysis of substitution among different advertising media outlets, led the authority to only make general statements about possible elements that would differentiate internet based advertising from other types of advertising. Here, CADE took the view of deciding on a narrowly defined market for Internet advertising, and noted only differences in what it called directed advertising, publicity where the consumer takes an active role in searching for a product or service, in contrast with creative advertising, where a message reaches a consumer with the intent of persuading him or her about the qualities of certain products or services and conquering him or her for a client or advertiser. It noted that Internet advertising could include either one of these types of publicity.

\section{Online Content Mergers}

\section{a. BtoB Factory/btoben.com Inc-Argentina}

For very early cases (c. 2000) there is a tendency to separate markets based on functional interchangeability. For example, Argentina's analysis of the merger between BtoB Factory and btoben.com Inc. in 2001, ${ }^{101}$ delved into the types of internet portals involved in the operation, noting that there were 3 distinguishable segments: business to consumers (B2C), business to business (B2B), and consumer to consumer $\left(\mathrm{C}_{2} \mathrm{C}\right)$. Based on this separation, the CNDC noted that there was no overlap between the business served by $\mathrm{BtoB}$ factory, the $\mathrm{B} 2 \mathrm{C}$ segment, and that served by btoben.com Inc., the $\mathrm{B} 2 \mathrm{~B}$ segment. According to $\mathrm{CNDC}$, since the focus of the analysis was on type of content provided by each party, the universe of existing and potential Internet content providers was sufficiently vast and barriers sufficiently low so as to deem any one company incapable of exercising significant influence.

b. Google Brasil/Akwan-Brazil

Brazil's SEAE reviewed the acquisition of Akwan by Google Brasil in 2005. ${ }^{102}$ Both companies were regarded as having a similar

${ }^{101}$ CNDC, Dictamen 197, B to B Factory Ventures S.A. y Consalvi International Inc. (Jan. 25 2001).

102 Department of Finance, Secretary for Economic Monitoring, Ato de Concentraçao 08012.006162/2005-47, Google Brasil Internet Ltda. y Akwan S.A. (Aug. 26 2005), available at http://www.abusando.org/denuncias/akwan-cade_google1.pdf. 
line of business: search for final consumers with revenues generated mainly through the sale of Internet advertising space. But the line of business was not translated into one two-sided market, but instead SEAE defined the relevant markets under review as (1) Internet search technology, (2) Internet advertising space, and (3) corporate search, which was an additional service offered by Akwan and not by Google. As was the case of Argentina before, two-sided markets were defined as two one-sided markets, and even within those services, there were further narrow classifications: in Internet search technology, the authority distinguished between search firms that offered their own searching capabilities and those that searched linking to other search engines. SEAE ultimately approved the transaction.

\section{Vertical Mergers: Internet Access and Online Content}

\section{a. Terra Networks/Infosel-Mexico}

There were three operations reviewed by Mexico's competition authority involving access providers and content producers, we look at the two that have more information on the analysis. ${ }^{103}$ The first, in 1999, where Terra Networks Mexico, a Spanish holding, purchased Infosel, a Mexican society offering media and news content through TV, telephony, messaging, internet, cable, electronic and telegraphic media. According to the CFC, Terra and Infosel coincided in the following relevant markets: financial information (content), financial electronic commerce, business to business, corporate services (internet service provision and solutions) and consumer services (internet service provision and websites). That same year, Via Net, which marketed Internet access services and other value added services (electronic data exchange, email, remote access to data bases), entered the Mexican market through the acquisition of Infoacces. Via Net, who offered Internet access services, installation and administration of networks and was authorized to offer value added services in various cities in Mexico. In both cases the Commission seems to have taken a mechanistic view of the markets it was reviewing: the type of content involved in the operation was

\footnotetext{
${ }_{103}$ CNT-138-1999 (Terra Networks México, SA de CV / Información Selectiva, SA de CV / Infoshare Communications, Inc / Interdata Infosel, SA de CV / Seguridad Privada, SA de CV), (October 4, 1999), available at http://www.cfc.gob.mx/docs/pdf/cnt-138-99.pdf; CNT-139-1999 (Via Net Works, Inc / Infoaccess, SA de CV), (Nov. 15, 1999), available at http://www.cfc.gob.mx/IMAGES/STORIES/PUBLICACIONES/GACETAS/o5SEPTIEMB REDICIEMBRE1999/G5-2CONCENTRACIONES.PDF; CNT-41-2004 (Flux International / MVS Net / Clearwire Corporation), (May 19, 2004), available at http://www.cfc.gob.mx/docs/pdf/cnt-41-2004.htm.pdf.
} 
noted, as was the service for each type of consumer (corporate or final consumers). However, true to its legal underpinnings, the CFC's analyses really focused on the effects: in both cases, the operation involved a new entrant, market definition was simply accessory to the final decision which focused on new entry, which is always good for competition, and hence received the Commission's approval.

\section{b. Terra Networks/Lycos Inc.-Mexico}

The 2000 merger between Terra Networks and Lycos Inc., which originated in the US was analyzed in Argentina as a vertical merger, that of an Internet access provider (Terra Networks, owned by Telefónica) and an online content provider, Lycos. ${ }^{104}$ Since the parties also coincided in online content provision, the market was also analyzed. As was the case of the AOL/Time Warner merger, two onesided markets were reviewed instead of one two-sided market. On the content production side, the CNDC argued that the parties coincided in search and content generation, with Lycos being a fairly new entrant. On the selling side of the platform, treated as an independent market from content production, an analysis similar to the AOL/Time Warner merger was undertaken.

\section{c. Google/Motorola-Mexico}

In 2011, the CFC reviewed the acquisition by Google of the Mexican subsidiaries of Motorola. ${ }^{105}$ Google's business included search and online advertising, as well as an open architecture operating system for mobile devices, Android. Motorola, marketed hardware (mobile devices and set-top boxes or STBs) in two business segments: mobile devices including smartphones and tablets, and home appliances including broadband access solutions. The Commission concluded that there were no horizontal overlaps between the parties, but a vertical relationship. Again, following its law in determining whether the merger had or could have as object or effect harm or hindrance to the competition process, it concluded that Google had no incentives to refuse or condition the sale of Android as a result of its acquisition of Motorola. Furthermore, it reasoned, there

\footnotetext{
104 CNDC, Dictamen 153, Terra Networks y Lycos Virginia (Nov. 17 2000), available at http://www.cndc.gov.ar/dictamenes/39_1_oo0153.pdf.

105 Federal Competition Comission, Expediente No. CNT 090-2011, Google Inc. and Motorola Mobility Holding (Dec. 8 2011), available at http://www.cfc.gob.mx/cfcresoluciones/docs/concentraciones/V414/1/1613669.pdf.
} 
were important competitors, including Nokia, Samsung, and LG. This led to an unconditional approval of the merger. ${ }^{106}$

\section{CONCLUSIONS}

In Latin America, modern antitrust institutions have emerged as a result of a changing perspective on the role that government should play in the economy. Public policy no longer considers the State as a key driver of economic growth; rather, modern antitrust policy in many of these countries regards markets as key to growth, so that interventions by an agency are usually limited to ensuring that firms follow a competitive process. As part of the efforts to "catch up" with more mature agencies, antitrust authorities in the region have made conscious efforts to "spell out" and follow best practices, particularly through guidelines. The implementation of best practices can be seen in certain antitrust analyses of Brazil, Mexico, and Argentina.

We presented three examples of casework, not necessarily related to internet-based industries, where these competition agencies have undertaken a market definition and power analysis that follows best practices. But some questions remain:

- Will agencies be able to apply these same concepts as they face mergers and investigations into "new economy" industries? They certainly do have the technical capabilities to do so.

- Will they have an awareness of the ways in which these practices ought to be reviewed in light of the special features that characterize these industries? We've presented considerations that must make up any competition analysis into this industry when reviewing competition matters, to ensure that their fast pace of change, multi-sided characteristics and attention seeking rivalry form part of any relevant market and power analysis.

106 Google/Motorola was also reviewed and approved by CADE. It is currently under review in Argentina by the CNDC. 
As one of us has argued in a previous paper, attention seeking by online rivals means that in many instances competition is not occurring "for the market" but "in the market" and this is an empirical question that authorities need to address. Analyses based on functional equivalence among services are wrong as attention rivals impose competitive constraints on each other across boundaries defined by the products and services they provide to consumers and advertisers.

Finally, while this degree of detail in the analyses of cases involving Internet-based industries have not yet been used by the competition agencies we study here, it is very likely that cases will be brought before these authorities soon. It is only a matter of time before we hopefully see a decision that provides in-depth analytical considerations about market definition and power concepts in a highly dynamic, multi-sided industry. At least that would be our wish. 
